九州大学学術情報リポジトリ

Kyushu University Institutional Repository

\title{
Carboniferous Brachiopods from Akiyoshi, Southwest Japan Part II
}

Yanagida, Juichi

Faculty of Science, Kyushu University

https://doi.org/10.5109/1543626

出版情報：九州大學理學部紀要：Series D, Geology. 16 (2)，pp.113-142，1965-05-31. Faculty of Science, Kyushu University バージョン：

権利関係 : 


\title{
Carboniferous Brachiopods from Akiyoshi, Southwest Japan* Part II
}

By

\author{
Juichi YANAGIDA
}

\begin{abstract}
This paper is the second part of "Carboniferous Brachiopods from Akiyoshi Southwest Japan". In part I thirteen species in ten genera were described from the Millerella zone of the "Uzura" quarry. In addition to the foregoing species, eight species among eight genera are described in this paper. They are Rugicostella nystiana (de KonincK), Rugosochonetes aff. R. hardrensis (PHILliPs), Orthotetes sp., Eomarginifera sp., "Spirifer" triangularis MARTIN, Dictyoclostus sp., Antiquatonia sp., and Prospira aff. $P$. burnettensis Maxwell. Summarizing, the complete fauna of brachiopods is correctly recognized as a faunal assemblage closely related to the Late Visean faunas of Europe, Asia, and Australia. It is concluded that the limestone of the "Uzura" quarry is Late Visean in age. A preliminary note concerning the age of the "Uzura" limestone is made on a brachiopod-coral assemblage newly found near the lowest part of the Akiyoshi limestone Group. The age of the lower formation of the Akiyoshi limestone Group and the boundary between the Visean and the Namurian are also discussed.
\end{abstract}

\section{Contents}

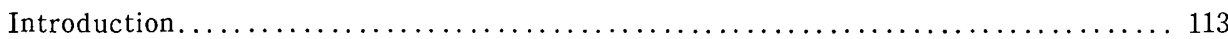

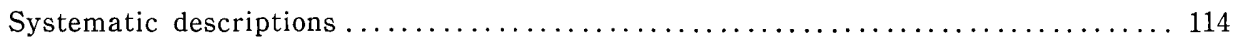

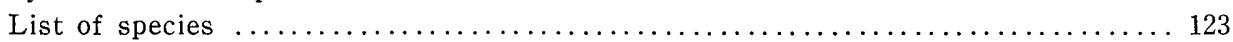

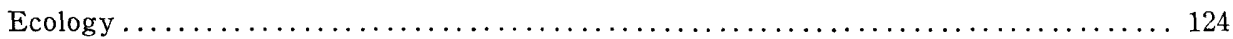

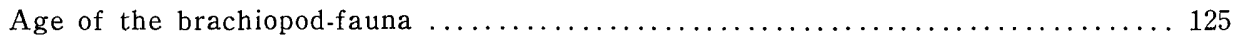

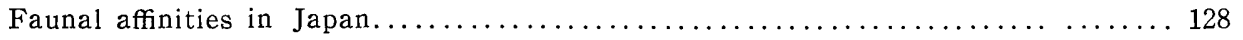

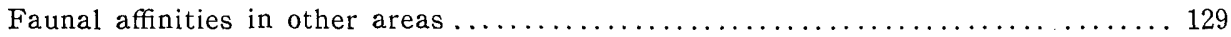

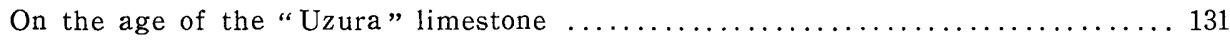

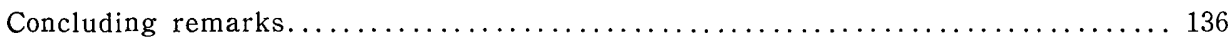

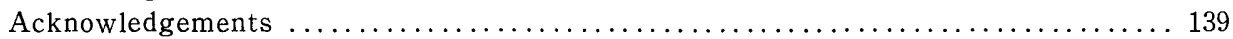

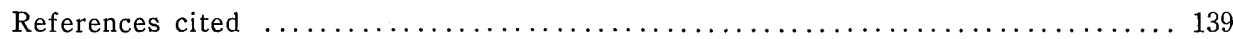

\section{Introduction}

Since OzAWA (1923) established the $C_{1}^{1}$ subzone=Nagatophyllum satoi subzone in the lowest part of the Akiyoshi limestone Group some differing opinions have held on the age of the lower part of the limestone group.

* Manuscript received September 30, 1964. 
Minato and Kato (1957) correlated the Nagatophyllum satoi subzone with the lower Upper Carboniferous (s. 1.) mainly on an assemblage of corals. ToRIYAMA (1958) found the Millerella zone in the lower part of the Profusulinella zone and established the Millerella sp. $\alpha$ zone.

After that Hasegawa (1958, 1963) and Minato and Kato (1963) reiterated their opinions that the age of the lowest part of the Akiyoshi limestone Group is the lower Upper Carboniferous (s. 1.) mainly based on corals.

In opposition to them MuRATA (1961) and OKIMURA (1963) on the basis of Foraminifera asserted the existence of the Lower Carboniferous in the lower part of the Akiyoshi limestone Group.

The author (1962) described some brachiopods from the Millerella limestone of the "Uzura" quarry. Some corals from the same quarry were also described by YAMAGIWA and OTA (1963). Twenty-one species among 18 genera of brachiopods and some corals including Nagatophyllum cf. N. satoi OzAwA were distinguished from the limestone.

It is concluded that the brachiopod fauna consists mainly of Late Visean elements. It is also recognized that the assemblage of the smaller foraminifers from the quarry is mainly represented by Visean elements, and their age is in harmony with that of the brachiopod fauna.

Recently many kinds of brachiopods and corals were found near the lowest part of the Akiyoshi limestone Group. Although palaeontological study of them is still unfinished they apparently represent elements of the Late Tournaisian to the Medial Visean.

Accordingly, the existence of the Lower Carboniferous in the Akiyoshi limestone Group is certain though the exact biostratigraphy of the underlying part of the Millerella zone has not yet been established. The age of the lowest part and the boundary between the Upper and Lower Carboniferous (s. 1.) still remain as unsolved problems in the Akiyoshi limestone Group.

\section{Systematic descriptions}

Family Institinidae MUIR-WoOD and COOPER, 1960

Genus Rugicostella MuIR-WoOd and COOPER, 1960

Type-species.-Productus nystianus de Koninck, 1842

Rugicostella nystiana (de KONINCK)

Pl. 25, figs. 1-5; Text-fig. 1

1842. Productus nystianus de Koninck, Description des animaux fossiles, p. 202, pl. 7, figs. 3a, b; pl. 9, figs. $7 a-c$; p1. 20, figs. 9a-d.

1847. Productus nystianus de Koninck, Recherches sur les animaux fossiles, Pt. I, pl. 14, figs. 5a-e.

1861. Productus nystianus, Davidson, Palaeontographical Soc. Mon. Brit. Foss. Brachiopoda, vol. 2, Pt. 5, no. 5, pp. 231-232, pl. 53, fig. 9.

Material.-The better preserved of eight incomplete specimens are as follows; GK-D 30105 (Pl. 25, figs. 4a-d), GK-D 30079 (Pl. 25, figs. 1a-d), GK-D 30080 (Pl. 25, 
figs. 3a-c), GK-D 30081 (P1. 25, figs. 2a-d), and GK-D 30082 (Pl. 25, fig. 5).

Description.-Shell small, subcircular; hinge line slightly shorter than or approximately equal to the shell-width. Pedicle valve strongly geniculated. Visceral disc of pedicle valve slightly convex and ornamented by low convex costae, numbering 3 to 4 in $5 \mathrm{~mm}$ near the anterior margin.

Approximate measurement of three specimens in $\mathrm{mm}$ :

\begin{tabular}{lrrr} 
& 1 & \multicolumn{1}{c}{2} & 3 \\
\hline length & 11.0 & 14.0 & \\
width & 12.0 & 16.5 & 12.4 \\
thickness & 7.0 & 9.5 & 6.0
\end{tabular}

Remarks.-The Akiyoshi specimens are poorly preserved, but are readily identified with the type-species of the genus by their peculiar external characters and size. Rugicostella nystiana has hither to been known only from the Visean of Visé, Belgium (de KonincK, 1842, 1847) and Yorkshire. England (DAvidson, 1861). This is the first record of Rugicostella from the Asiatic region.

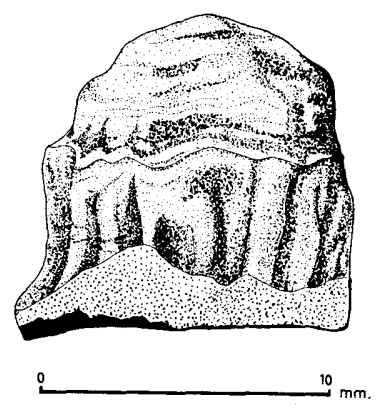

Fig. 1. Inked drawing of anterior view of Rugicostella nystiana (DE Koninck).

Family Chonetidae Hall and Clarke, 1895

Subfamily Chonetinae HALL and Clarke, 1895

Genus Rugosochonetes SoKolskAYA, 1950

Type-species.-Orthis hardrensis PHILliPs

Rugosochonetes aff. R. hardrensis (PHILLIPS)

P1. 27, figs. 2-8.

Compare.-

1841. Orthis hardrensis Phillips, Mem. Geol. Surv. Gt. Britain I, p. 138, pl. 58, figs. 104 b-d.

1843. Chonetes laguessiana de Koninck, Description des animaux fossiles, p. 211, pl. 12, figs. $4 \mathrm{a}-\mathrm{b}$.

1858. Chonetes hardrensis, Davidson, Palaeont. Soc., vol. 2, pt. 2, pp. 186-188, pl. 47, figs. 12-18.

1928. Chonetes hardrensis var. kansuensis CHAO, Palaeont. Sinica, ser. B, vol. 5, fasc. 3, pp. 10-12, pl. 1, figs. 1-6.

1962. Chonetes klondikia Armstrong, New Mexico Bur. Mine., Mem. 8, pp. 47-48, pl. 6, figs. $1-7$.

Material.-Seven specimens are available of which three are pedicle valves and the others are internal casts of brachial valves; GK-D 30083 (PI. 27, fig. 4), GK-D 30084 (Pl. 27, fig. 5), GK-D 30085 (P1. 27, fig. 6), GK-D 30086 (PI. 27, fig. 3), GK-D 30087 (Pl. 27, fig. 2), GK-D 30088 (Pl. 27, fig. 7), and GK-D 30089 (Pl. 27, fig. 8).

Description.-Small and transversely subcircular, the greatest width at, or slghtly anterior to the hinge line. Cardinal extremities bluntly rounded, forming an angle of about $90^{\circ}$. Beak very small, not incurved over the hinge-line. Pedicle valve slightly and uniformly convex the convexity decreasing laterally from the median portion to the cardinal extremities. Ears flat. No sulcus on venter. Surface orna- 
mented by very fine, closely arranged capillae, 6 to 7 in $1 \mathrm{~mm}$ near the anterior margin, and more than 80 around the margin of the pedicle valve. Capillae bifurcating near the anterior extremity, and imperceptible or absent on ears. Concentric growth lines faintly observed in a specimen near the anterior margin.

Brachial valve moderately concave, having convexity like of the opposite one. Ears flat. Interior surface of brachial valve strongly papillose except for ears. Other internal characters not preserved except for a trace of very shallow sockets and socket plates in the cardinal region.

Measurements of six specimens in $\mathrm{mm}$ :

\begin{tabular}{lrrrrrrr}
\multicolumn{2}{c}{ pedicle valve } & \multicolumn{9}{c}{} & \multicolumn{3}{c}{ brachial valve } \\
& 1 & 2 & 3 & & 1 & 2 & 3 \\
\hline length & 7.0 & 7.1 & 6.0 & length & 7.0 & 7.5 & 8.0 \\
width & 11.5 & 11.2 & 9.4 & width & 10.0 & 10.5 & 11.5 \\
width at hinge & 10.0 & & 7.6 & width at hinge & 10.0 & & 10.7 \\
height & 2.4 & 2.1 & 1.5 & & & &
\end{tabular}

Remarks.-The Akiyoshi specimens are characterized by very small size, weakly concavo-convex shell and very fine and numerous capillae which bifurcate near the anterior margin. General outline and surface sculpture indicate the closest affinity to those of the type-species from England. However the Akiyoshi species is distinguished from the latter by its uniformly small size. Very fine and numerous capillae on the valves are in harmony with those of Chonetes laguessiana de Koninck. However, the latter species is clearly distinguished from the Akiyoshi one by its more transverse outline.

In the Japanese Lower Carboniferous there are reports of occurrences of Chonetes hardrensis and Ch. sp. from the Ohdaira Formation of the Kitakami massif by Minato et al. (1953).

The Chinese Visean species, Chonetes hardrensis var. kansuensis CHAO from the Choniukou Formation of Kansu, shows resemblance to the Akiyoshi one in its size and outline. But the former species differs from the latter in having a distinct sulcus on the pedicle valve.

The American Mississippian species Chonetes klondikia ARMSTRONG from the Keating Formation of New Mexico and Arizona is similar to the Akiyoshi one in its size and ornament but has a weaker sulcus and more circular outline than the latter.

Family Spiriferidae KING, 1846

Subfamily Spiriferinae KING, 1846

Genus Spirifer SowERBY, 1816, emend

Remarks.-The generic position of the Akiyoshi specimens herein described is in doubt. Spirifer triangularis MARTIN was included in the genus Fusella McCoy by BuckMAN (1906, p. 29). Much confusion devoloped from this revised diagnosis of the genus. The type-species of Fusella, Spirifer fusiformis PHILlips (1836, p. 217, pl. 9, figs. 10-11 ; DAVIDSON, 1862, pl. 13, figs. 15, 15a), has a finely striated shell to the contrary to the diagnosis by BuckMAN. He stated that the type is in the smooth stage when 
nearly all ribs have been lost. PHILLIPs original specimen, however, is imperfect by exfoliation as DAVIDSON pointed out $(1862$, p. 57) and the internal structures are unknown. Such being the case it is impossible to know the character of Fusella until its type species is precisely defined by study of well preserved materials from the original locality. Spirifer triangularis, also, does not seem to belong to Spirifer (s. s.) in its outline and ornament. Taking into consideration these problems I prefer to refer the Akiyoshi species to the genus Spirifer until the type species of Fusella is clearly redefined.

\section{Type-species.-Anomites striatus MARTIN, 1809 \\ “Spirifer" triangularis MARTIN \\ Pl. 26, figs 1,3 ; Text-fig. 2}

1843. Spirifer triangularis, de Koninck, Animaux fossils de la Belgique, p. 234, pl. 15, fig. 1.

1857. Sp. triangularis, Davidson, Palaeont. Soc. Mon. Brit. Foss. Brachiopoda, vol. 2, part 5, pp. 27-29, pl. 5, figs. 16-24.

1887. Sp. triangularis, de KonINCK, Ann. Mus. Roy. Hist. Nat. Belgique, vol. 14, pp. 124125, pl. 29 , figs. $7-15$.

Material.-Two small specimens, one incomplete, GK-D 30109 (Pl. 26, figs. 1a-d), and a pedicle valve, GK-D 30090 (Pl. 26, figs. 3a-c), are available, of which the latter is immature.

Description.-Biconvex, small, and very transverse, the greatest shell-width at the hinge line, approximately $2 \frac{1}{2}$ times as wide as long.

Cardinal extremities alate; cardinal angles $35^{\circ}$ to $40^{\circ}$. Cardinal area remarkably wide, slightly concave, and tapers abruptly at the lateral margins. Cardinal ridges sharp with acute angles to lateral slopes. Denticle grooves weak, disposed on the cardinal area except for the beak region where they are obsolete or absent. Three denticles in $1 \mathrm{~mm}$, crossed by microscopic growth lines well preserved in the umbonal region. The delthyrium about $3 \mathrm{~mm}$ wide at the hinge making an angle of about $40^{\circ}$. Median sulcus narrow bounded on both sides by distinct costae. Median costa low and distinct occuring at about $2 \mathrm{~mm}$ from the beak and increasing in strength anteriorly. Lateral slopes covered by simple, round-topped costae. Without either bifurcation or intercaltion. Four costae appear on each side of sulcus in younger shells and 6 to 7 in adult ones. Costae rapidly decreasing in strength toward the cardinal margins, the outer 1 or 2 very faint. Valley between the costae shallow and round with approximately same width as the costae. Both valves covered by regularly and closely arranged concentric lamellae which number 3 to 4 in $1 \mathrm{~mm}$ near the anterior margin.

Brachial valve less convex than the pedicle one; median fold narrow, acute and rapidly increasing in height anteriorly. Shell substance impunctate.

Measurements in mm.-Larger specimen (GK-D 30089); $10.5 \mathrm{~mm}$ long, ca. $26.0 \mathrm{~mm}$ wide, and $8.0 \mathrm{~mm}$ thick. Smaller pedicle valve (GK-D 30090); $7.0 \mathrm{~mm}$ long and 10.0 mm wide.

Remarks.-The Akiyoshi specimens are characterized by strongly transverse 

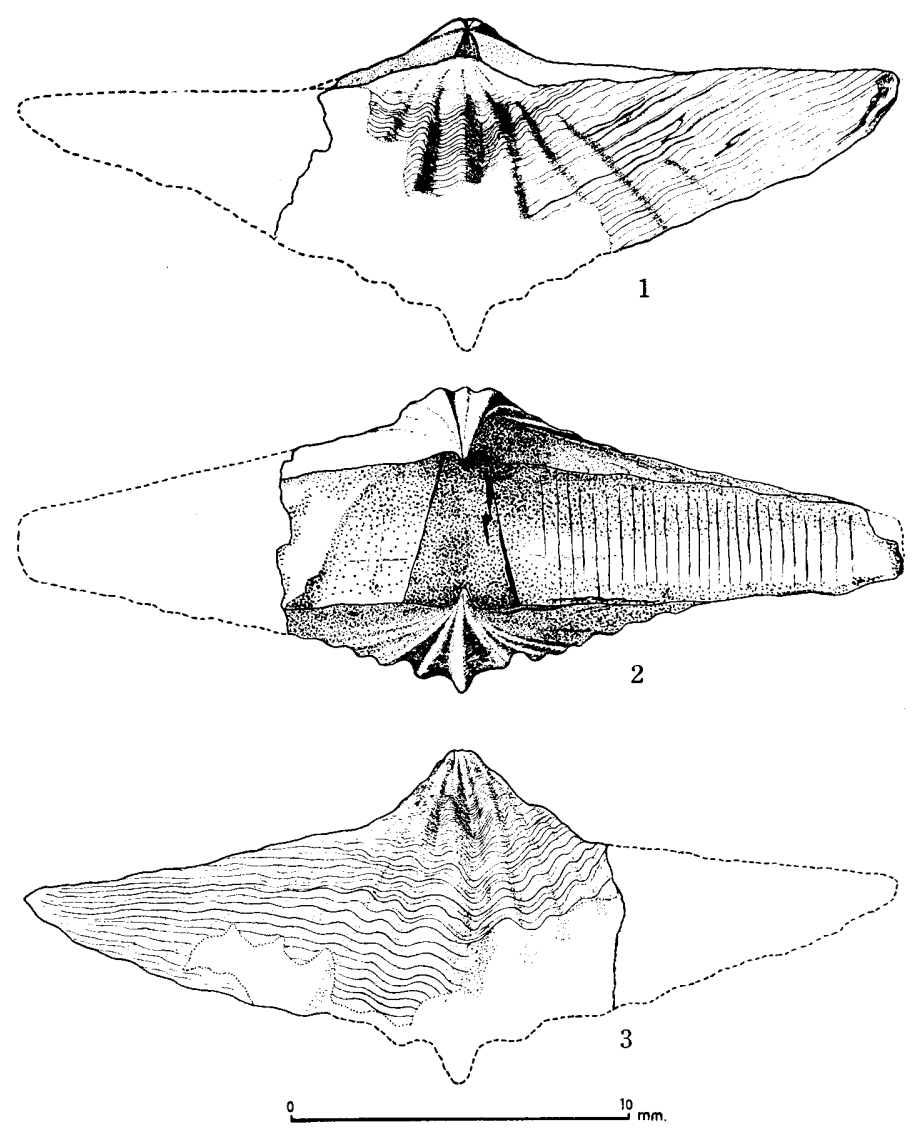

Fig. 2. Inked drawing of "Spirifer" triangularis MARTIN; 1 , brachial, 2 , posterior, 3 , pedicle views.

outline, a median costa in the sulcus, acutely projected fold, and numerous concentric growth lamellae. Those characters are in harmony with those of the species of the Visean of England and Belgium. Slight differences in the Akiyoshi specimens from the original one are smaller size, transversely more elongate shell, and more remarkable concentric lamellae. The last character was well revealed in the Belgium specimen (de KONINCK, 1887, pl. 29, figs. 16-24). Generally speaking the Akiyoshi species is more transverse in form and has weaker and fewer ribs than the European species.

Alispirifer laminosus (CAMPBELL, 1961, pp. 435-437, pl. 55, figs. 17-23) from the Upper Carboniferous Booral and Isacs Formations of New South Wales, Australia resembles the Akiyoshi species in its outline and external characters. But the latter is clearly distinguished from the former by its acute fold and a remarkable costa in the sulcus. Alispirifer usually lacks the costa in the sulcus and rarely has a very weak plication. It also has fine radial lirae on the surface, which were not observed in the Akiyoshi species.

Mucrospirifer ? sp. (SARYcheva, et al, 1963, p. 267, pl. 43, fig. 6) from the Carboniferous Ostrogskaya Group of the Kuznetsk basin closely resembles the Akiyoshi 
species in its size, outline, and ornament. Both species may be closely related to each other. It is interesting that the age of the Ostrogskaya Group is from the Latest Visean to the Namurian.

Subfamily Cyrtiinae FredERICKS, 1926

Genus Prospira Maxwell, 1954

Type-species.-Prospira typa MAXwell, 1954

Prospira aff. P. burnettensis MAXwelL

Pl. 26, fig. 2; Text-fig. 3

Compare.-

1961. Prospira burnettensis Maxwell, Jour. Palaeont., vol. 35, no. 1, pp. 91-92, pl. 20, figs. 1-7.

Material.-One pedicle valve, GK-D 30091 (Pl. 26, figs. 2a-d).

Description.-Small, subtriangular and moderately convex with the maximum convexity at the umbonal region. Lateral slopes becoming flat toward the cardinal extremities which are slightly alate. Widest along the hinge line with the width approximately $1 \frac{1}{2}$ times the length. Beak pointed, slightly incurved over the narrow area. Sulcus well defined, bounded by strong simple radial costae. Median costa distinct in sulcus, not bifurcated, but bounded by a pair of costae arising from the bounding costae between the sulcus and the lateral slopes. Lateral slopes bearing 18 rounded costae near the anterior margin, usually simple, occasionally with new costae intercalated, and decreasing in strength laterally and posteriorly. Microscopic radial striae occurring on the shell surface. Regularly spaced, anteriorly distinct, and occasionally imbricate concentric growth lines occur on the whole surface. Shell substance impunctate.

Dimensions: $9.0 \mathrm{~mm}$ long, $14.0 \mathrm{~mm}$ wide, and $4.0 \mathrm{~mm}$ thick.

Remarks.-The Akiyoshi species is characterized by transverse outline of about $2: 3$ of length-width ratio, median sulcus with weak costae, concentric growth lines, and microscopic radial striae. From these characters the Akiyoshi species is closely related to Prospira burnettensis from the Upper Tournaisian of Queensland described by MAxwell (1961). Slight differences of the former species from the Australian one are in its more distinct growth lines and stronger simple costae in the sulcus. Ribs on both wings are simple in the Australian species. On the other hand the Akiyoshi one increases in number of ribs by intercalation which occurs occasionally.

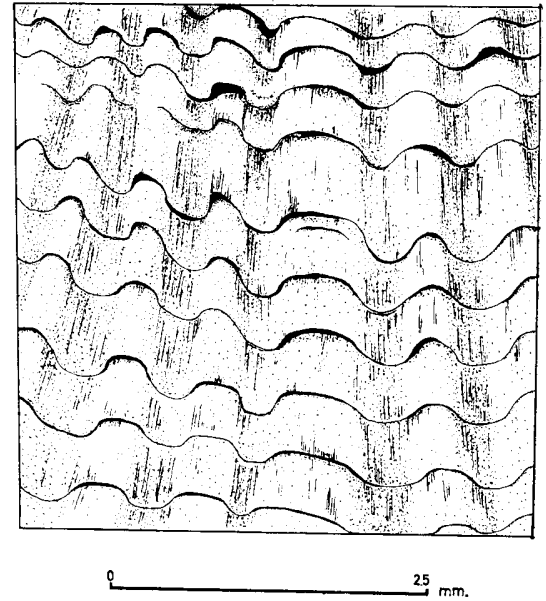

Fig. 3. Inked drawing of enlarged view of shell-surface of Prospira aff. P. burnettensis (MAXWELl). 
Of European species, it is similar to Spirifer trigonalis MARTIN, figured by DAvidson (1865, pp. 29-31, pl. 5, figs. 25-34) and de KonincK (1887, pp. 121-123, pl. 26, figs. 5-8, pl. 28, figs. 7, 8, 24-44, 48) from the Visean of England and Belgium.

In China CHAO (1927, pp. 65-67, pl. 8, figs. 1, 2) has described Brachythyrina kansuensis from the Visean Choniukou Formation; his species shows resemblance to $P$. aff. $P$. burnettensis in external characters.

Family Orthotetidae WAAGEN, 1884

Subfamily Orthotetinae WAAGEN, 1884

Genus Orthotetes Fischer de WALDHEIM, 1829

Type-species.-Orthotetes radiata FISCHER, 1850

Orthotetes sp.

Pl. 27, figs. 9-14.

Material.-Several incomplete specimens are figured under the heading; GK-D 30106 (Pl. 27, fig. 12), GK-D 30093 (Pl. 27, fig. 9), GK-D 30094 (Pl. 27, fig. 13).

Description.--Large, subcircular, suggesting the greatest width near the hinge. Pedicle valve flat or slightly resupinate. Concentric growth folds irregular. Ornament consisting of narrow, sharp costae increasing in number by intercalation, 7 to 8 in $5 \mathrm{~mm}$ in anterior portion of adults, separated by flat, broad interspaces of about $1 \mathrm{~mm}$ width. Whole surface covered by very fine, closely spaced growth lines. Brachial valve slightly and uniformely convex with the ornament similar to that of the pedicle valve.

Internal structures not preserved except in a fragmentary specimen in which a crural plate is distinctly observed.

Correct dimensions uncertain. Largest specimen suggests about 60 to $70 \mathrm{~mm}$ wide and 50 to $60 \mathrm{~mm}$ long.

Remarks.-The Akiyoshi specimens are characterized by their large size, slightly convex brachial valves, closely and uniformly arranged radial costae, and short, heavy crural plate. From these characters it is considered that the Akiyoshi species has a close relation with that of the Lower Carboniferous genus Werriea (CAMPBELL, 1957, pp. 45-47) although the internal structures of the pedicle valve of the former is not known.

In the Japanese Lower Carboniferous, Orthotetes keokuk (HALL) and Orthotetes sp. were described by Minato (1952) from an impure limestone of the Arisu Series of the Kitakami massif. The Akiyoshi specimens and the Kitakami ones are similar with each other in external configuration, the former are slightly larger in size and coarser in radial ornament than the latter.

Family Marginiferidae STEHLI, 1954

Subfamily Marginiferinae STEHLI, 1954

Genus Eomarginifera MUIR-Wood, 1930 
Type-species.-Productus longispinus SowERBY, 1814

Eomarginifera sp.

P1. 28, figs. 3, 4, 7, 8 ; P1. 27, fig. 1 .

Material.-Four incomplete pedicle valves and two fragmentary brachial ones: GK-D 30095 (Pl. 28, fig. 7), GK-D 30096 (Pl. 28, figs. 3a-c), GK-D 30097 (Pl. 28, fig. 8), GK-D 30098 (Pl. 28, fig. 4), and GK-D 30099 (Pl. 27, figs. 1a-c).

Description.-Small, subcircular to subquadrate; profile subgeniculate to subcircular ; umbo bluntly pointed and slightly incurved over the hinge line; venter weakly and uniformly rounded. Maximum width slightly anterior to the hinge line. Cardinal extremities rectangular to slightly mucronate. Ears small. Visceral disc of pedicle valve subcircular and with several weak rugae. Costellae round-topped, low, and irregular but well-developed on the whole surface and occasionally bifurcated, about 8 or 9 of them in $5 \mathrm{~mm}$ near the anterior margin of the trail. Spines and spine bases not preserved. Pedicle valve with ginglymoid joint. Dimensions of a pedicle valve (GK-D 30095): length $13.5 \mathrm{~mm}$; width $13.0 \mathrm{~mm}$; hinge $12.0 \mathrm{~mm}$; height $4 \mathrm{~mm}$. Internal surface along the hinge line of pedicle valve slightly concave and showing more or less a ginglymoid articulation.

Remarks.-The Akiyoshi specimens superficially resemble those of Eomarginifera paradoxa (CAMPBELL) from the Middle Visean of Watts, Babbinboon, New South Wales. The species was originally described by CAMPBELL (1957) under the name of Dictyoclostus paradoxus and was correlated with the Late Tournaisian.*

Family Dictyoclostidae STEHLI, 1954

Subfamily Dictyoclostinae STEHLI, 1954

Genus Dictyoclostus MuIR-Wood, 1930

Type-species.-Productus semireticulatus (MARTIN), 1809

Dictyoclostus sp.

P1. 28, figs. 5,6

Material.-A pedicle valve (GK-D 30101, Pl. 28, figs. 5a-c) and a small external mould of a brachial valve (GK-D 30102, Pl. 28, figs. 6a-c).

Description.--Pedicle valve medium and subcircular with mucronate cardinal extremities. Visceral disc slightly convex. Hinge line slightly shorter than the greatest width which is at the mid portion of the valve. Umbo moderately large and pointed, but not incurved beyond the hinge line. Venter uniformly convex and flanks gently sloping. No median sulcus. Costae well developed on the whole surface, increasing in number by bifurcation and intercalation, 8 to 9 in $5 \mathrm{~mm}$ on the median portion near the anterior margin. Rugae strong and irregular on the whole surface, specially stronger than the costae, strong on the flanks, and numbering about 25 on whole surface. Three to 5 small spine bases indistinctly observed on the trail.

Brachial valve moderately geniculate, visceral disc round and flat, or slightly

* This emendation was shown by a personal communication. 
concave. Ears flat. Ornamentation similar to that of the pedicle valve.

Dimensions : pedicle valve; $27.5 \mathrm{~mm}$ wide, $24.5 \mathrm{~mm}$ long, $21.5 \mathrm{~mm}$ hinge line, $8.5 \mathrm{~mm}$ high ; brachial valve ; $18.0 \mathrm{~mm}$ wide, $13.5 \mathrm{~mm}$ long, $13.5 \mathrm{~mm}$ hinge line, $5.8 \mathrm{~mm}$ high.

Remarks.-Although the Akiyoshi specimens are represented by slightly exfoliated shells and the internal characters are unknown, they are characterized by the subround shape with slightly mucronate ears, evenly arched profile both longitudinally and laterally, weak costae, strong rugae, and shallow but sharply geniculate brachial valve. These characters resemble those of Eomarginifera paradoxa (CAMPBELL) from the Middle Visean of New South Wales. However, the dimensions of the pedicle valve are larger in the Akiyoshi specimens and the rugae more developed than those of the Australian species.

The American Dictyoclostus welleri (MATHER) from the Morrow Group is similar to the Akiyoshi species in its outline and lack of a median sulcus, but is differs from the latter in its coarser costation, weaker rugae, and stronger convexity.

It is worthy of note that the Russian Upper Carboniferous Productus volgensis described by STuckenBeRG (1905, p. 65, pl. 7, figs. 1, 2; pl. 9, figs. 2a, b) from Samara appears to be closely similar to the Akiyoshi species in external characters. Slight differences appear in the concentric rugae which are stronger and more numerous. in the Akiyoshi species than the Russian one. The costae of the Russian species are coarser than the other.

A variety of $P$. volgensis described by ReED (1925, pp. 35-36, pl. 3, fig. 11) from the Upper Carboniferous of Pamir also resembles the Akiyoshi species in external characters, but it is distinguished from the latter by the same characters above stated.

\section{Genus Antiquatonia Miloradovich, 1945}

Remarks.--Although the Akiyoshi specimens are poorly preserved, they are very weakly rugose on the visceral disc only and the reticulation is hardly visible. Costae, on the contrary, are well defined over the whole surface except ears. The pedicle valve ornament and the relatively broad visceral disc of the Akiyoshi specimens show close resemblance to those of the genus Pugilis. However, the former are clearly distinguished from the latter by having the diagonal ridges which separate the ears from the visceral disc.

Type-species.-Productus antiquatus SowERBy, 1821

Antiquatonia sp.

Pl. 28, figs. 1, 2 ; Text-fig. 4

Material.-Two incomplete pedicle valves, GK-D 30103 (P1. 28, figs. 2a-d) and GK-D 30104 (Pl. 28, figs. 1a-d).

Description.-Shell small, subrectangular, the greatest width at the hinge line. Pedicle valve strongly convex with a short, flattened trail, steep flanks, and the greatest convexity near the hinge line. Beak pointed with a slightly inflated umbo which extends more or less over the hinge line. Visceral disc weakly and uniformly convex. Ears well developed and moderately convex, a pair of low and round ridges. 
occurring near the umbo and diverging anterolaterally separating the ears from the umbonal flanks. Ridges extending about $10 \mathrm{~mm}$ from the beak and merging into the lower part of the flanks. Whole surface excepting the ears covered by numerous and round costae. Bifurcations occur on the visceral disc. About 10 costae in $5 \mathrm{~mm}$ near the anterior margin and about 4 to 5 rugae faintly observable in the

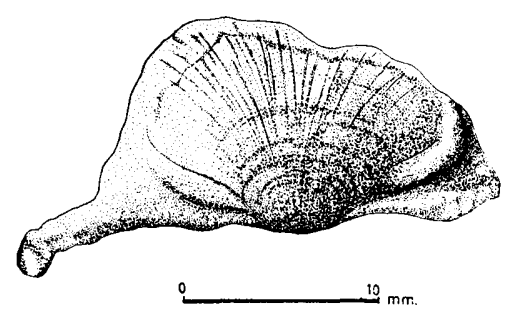

Fig. 4. Inked drawing of posterior view of Antiquatonia sp. posterior portion of the visceral disc. Reticulation hardly recognizable. Microscopic growth striae of about 5 in $1 \mathrm{~mm}$ visible on the trail. About 4 to 5 spine bases of small diameter indistinctly scattered on trail, visceral disc, and the ridges on the flanks, those on the ridges disposed near the anterior extremities of each one.

Dimensions of two pedicle valves: width, $20.0 \mathrm{~mm}, 23.0 \mathrm{~mm}$; length, $12.5 \mathrm{~mm}$ $17.0 \mathrm{~mm}$; height, $8.5 \mathrm{~mm}, 9.0 \mathrm{~mm}$.

Remarks.-The Akiyoshi specimens are uniformly small. It is considered, however, that they are probably adults from their external characters. The greatest convexity near the hinge line, flat trail, largely convex ears, and weak rugae reveal the specific character of the Akiyoshi species. There seems to be no identical species of the genus with the Akiyoshi one as far as I am aware.

\section{List of species}

The following species were found and described from the "Uzura" quarry of Akiyoshi.

Specific name Number of specimens

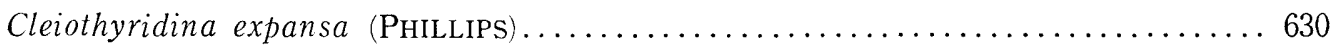

Cleiothyridina royssii (L'EvEILLE) ................................ 287

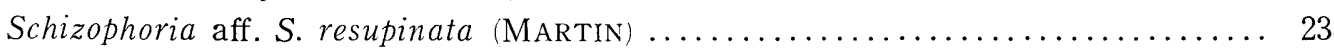

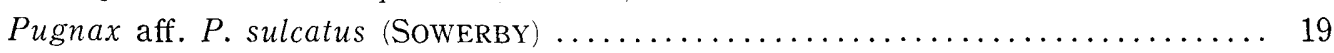

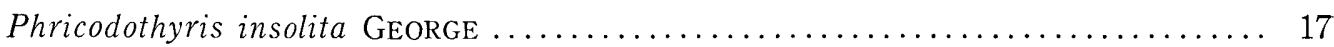

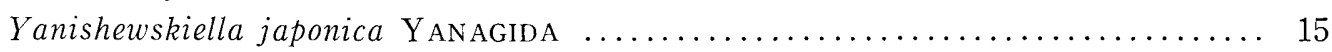

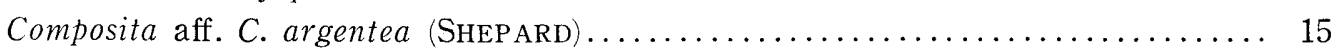

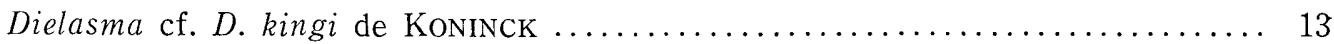

Actinoconchus planosulcatus (PHILlips) . ......................... 9

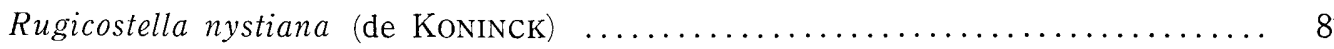

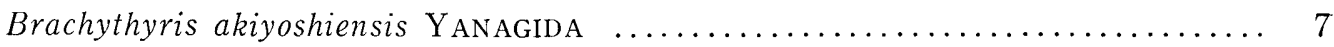

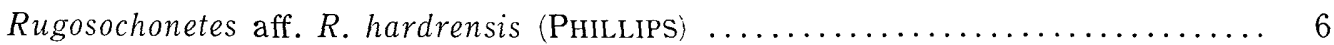

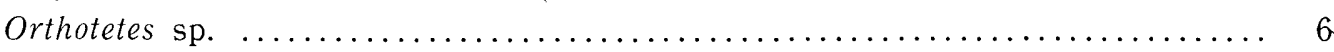

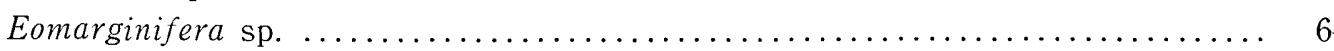

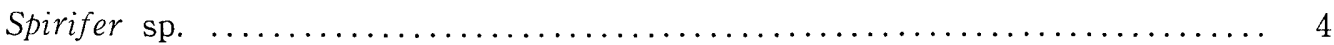

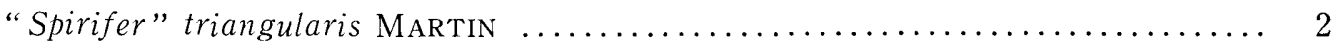



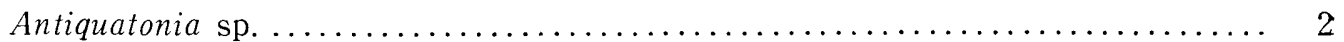




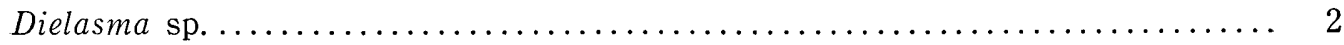

Prospira aff. P. burnettensis MAXwELL........................... 1



\section{Ecology}

The limestone of the Uzura quarry is massive and fossiliferous (YANAGIDA, 1962, p. 89) and in a textural sense is a calcirudite. It is a bioclastic breccia composed of brachiopods, corals, fusulinids, pelecypods, gastropods, and other organisms, and their fragments. The limestone contains a great number and many kinds of brachiopods which form the majority of its fossils. The matrix of the calcirudite can be divided into two groups, the calcarenite of those of fine sand size and bioclastic calcarenite mainly composed of fine fragments of brachiopod-shells. Each bioclastic clacirudite containing different grain-size of matrix shows gradual mergence with the other both longitudinally and laterally. It is observed in usual about the matrices that each of the calcarenite and bioclastic calcarenite is gray and dark gray respectively.

It is very difficult to discover the general trend of the limestone at the quarry as it is massive. However, it is considered from the arrangement of the brachiopodshells that the strike of the limestone is from east to west and it dips gently southward at about $30^{\circ}$. This fossiliferous limestone is more than $50 \mathrm{~m}$ thick and more than $60 \mathrm{~m}$ in widest extent. Although its whole aspect can not be recognized correctly because of poor exposures, abrupt and gradual extinction of the mass of brachiopodshells is partly observed near the margin of the shell-bed. The boundary between the fossiliferous and non-fossiliferous parts irregularly interfinger with each other. The chemical compositions of some specimens of the bioclastic calcirudite, and the matrix show close resemblance to each other.

Most of the brachiopod fossils at the quarry are composed of shells of Cleiothyridina

Table 1. Chemical composition.

\begin{tabular}{|c|c|c|c|c|c|c|c|c|}
\hline & $\mathrm{SiO}_{2}$ & $\mathrm{Al}_{2} \mathrm{O}_{3}$ & $\mathrm{Fe}_{2} \mathrm{O}_{3}$ & $\mathrm{CaO}$ & $\mathrm{MgO}$ & $\mathrm{SO}_{3}$ & $\begin{array}{l}\text { Loss on } \\
\text { ignition }\end{array}$ & Total \\
\hline 1 & 0.06 & 0.08 & 0.04 & 55.36 & 0.54 & 0 & 43. 08 & 99.16 \\
\hline 2 & 0.08 & 0.03 & 0.09 & 55.11 & 0.70 & 0 & 43. 30 & 99.31 \\
\hline 3 & 0.10 & 0.04 & 0.10 & 55.10 & 0.54 & 0 & 43. 53 & 99.41 \\
\hline 4 & 0.10 & 0.08 & 0.06 & 55.41 & 0.50 & 0 & 43. 14 & 99.29 \\
\hline 5 & 0.12 & 0.05 & 0.05 & 55.48 & 0.49 & 0 & 43. 40 & 99.59 \\
\hline 6 & 0.06 & 0.05 & 0.09 & 55.32 & 0.48 & 0.03 & 43. 69 & 99.72 \\
\hline 7 & 0.04 & 0.04 & 0.04 & 55.15 & 0.69 & 0.08 & 44. 03 & 100.07 \\
\hline 8 & 0.06 & 0.06 & 0.04 & 55.13 & 0.60 & 0.03 & 43. 83 & 99.75 \\
\hline 9 & 0.04 & 0.02 & 0.04 & 55.25 & 0.54 & 0.04 & 43.76 & 99.69 \\
\hline 10 & 0.06 & 0.05 & 0.15 & 55.45 & 0.33 & 0.22 & 43. 82 & 100.08 \\
\hline
\end{tabular}

1-9. Fine calcirudites of the "Uzura" quarry.

10. Shell substance of a brachiopod specimen belonging to Cleiothyridina expansa (Phillips). [Analyst: Masao Nakamura] 
expansa and $C$. royssii making up approximately 80\%. Among the other genera, Eomarginifera, Antiquatonia, Rugicostella, Orthotetes, Prospira, and Rugosochonetes are very rare. The faunal differences in different horizons in the limestone are not recognized.

Most valves are disarticulated. This character is especially well seen in the larger shells of Cleiothyridina, Orthotetes, and Spirifer etc. but the smaller ones, such as Composita, Dielasma, Pugnax, and Yanishewskiella usually have both valves associated.

Occasionally the larger shells are well polished and rounded by wave or current action. However, preservation is generally good and even the minute ornament of shell-surface is fully preserved in the larger shells. Small brachiopods and remains. of other small organisms are always preserved in excellent condition. The sorting of the limestone is very poor, as shown by assemblages of miscellaneous organisms of every stage of growth. Orthotetes, Rugicostella, and Spirifer are usually found in the calcarenite. Waves or currents had an important effect on sweeping the organisms during deposition. But sorting of them was rather poor. Most of the brachiopods and other organisms were transported in short distance after their death from their original habitat. A shallow water is indicated.

Dissociated valves are usually scattered in heaps. Most of the brachiopod valves are arranged with convex side up. Therefore the limestone of the quarry is in normal order from the lower to the upper.

The upper part of the limestone at the quarry of about $15 \mathrm{~m}$ thick is especially characterized by a number of corals often in colonies. Their calyces are directed upward in all occurreces. A small number of brachiopods are associated with the corals. The valves are usually separated. The occurrence of corals indicates that they are apparently autochthonous. The upper part conformably overlies the lower brachiopod limestone. They gradually merge into each other and are composed of the same matrices. It is considered that the limestone of the upper part has the character of a reef.

\section{Age of the brachiopod-fauna}

For establishing the age of the limestoneo $f$ the "Uzura" quarry, abundance of fossils offers several means. On the basis of brachiopods, the fauna is divided into three groups, the first group indicates Visean age, the second indicates an age from Tournaisian to the Visean, and the third has a longer range than other two.

The first group of Visean age consists of the following species: Phricodothyris insolita GEORGE, the typical species of the Upper Visean $\mathrm{D}_{2}$ subzone of England, the genus is occasional below the Visean elsewhere in the world; Brachythyris akiyoshiensis related to $B$. pinguis (SowERBY), from the $C_{1}$ to $C_{2}$ subzones of England; Spirifer aff. $S$. liangchowensis $\mathrm{CHAO}$, closely related to $S$. liangchowensis from the Visean Choniukou Formation of northwest China and $S$. cf. S. liangchowensis from the Visean of Queensland of Australia, the Chinese species may by morphologically more advanced than the Japanese one; "Spirifer" triangularis MARTIN, a representative Visean species 
in England and western Europe, but Akiyoshi species may be morphologically more primitive than the European one; Dielasma sp. related to Dielasma attenuatum (MARTIN) which is the representative species of the Visean of western Europe and England; Yanishewskiella japonica closely related to $Y$. angulata (YANISHEWSKY) which is the typical Visean species in Ferghana and western Europe; Pugnax aff. P. sulcatus (SOWERBY), related to P. sulcatus (SOWERBY) which is common in the Lower Visean of England and western Europe; Rugicostella nystiana (DE KonINCK), only known occurrence in the Visean of Belgium and England outside of Japan; Cleiothyridina expansa (PHILl.IPS), the most numerous brachiopod in Akiyoshi, ranges from the Lower Visean $S_{1}$ subzone up to the Upper Visean $D_{3}$ subzone in England showing its peak of development from $\mathrm{S}_{2}$ to $\mathrm{D}_{1}$ subzone; Orthotetes sp., closely resembles Werriea australis CAMPBELL which is a representative species of the Australian Middle Visean.

The second group, ranging in age from the Tournaisian to the Visean consists of the following: Dielasma cf. D. kingi de Koninck, closely comparable with the Upper Tournaisian to the Lower Visean D. kingi of Belgium; Prospira aff. P. burnettensis MAXWELL, closely related to $P$. burnettensis from the Upper Tournaisian of Queensland, northeast Australia, and the Japanese species may be morphologically more advanced than the another, and in Australia the genus is recorded from the Upper Tournaisian to Lower Visean; Schizophoria aff. S. resupinata (MARTIN), closely related to $S$. resupinata which is cosmopolitan and ranges from the Tournaisian $Z_{2}$ subzone up to the Lower Visean $C_{2}$ subzone in England and is most abundant in the Upper Tournaisian; Actinoconchus planosulcatus (PHILlips), first appears in the $\mathrm{C}$ zone and ranges to the Upper Visean $D_{2}$ subzone in England showing its peak in the Visean $S_{1}$ to $D_{1}$ subzones, and also occures in the Visean of Belgium.

The species which belong to the third group have ranges longer than the other two groups. Amog them Cleiothyridina royssii (L'EveILLE) is very numerous next to $C l$. expansa. This species ranges from the Etroeungtian $\mathrm{K}_{\mathrm{m}}$ subzone to the Visean $\mathrm{C}_{2}$ subzone in England and shows its acme at about the Tournaisian $Z_{1}$ subzone. It is also well known in the Tournaisian of Belgium. In Japan it is known from the Kitakami Etroeungtian Hikoroichi Formation up to the lower half of the Ohdaira Formation; Rugosochonetes aff. $R$. hardrensis (PHILliPs), closely related to $R$. hardrensis which ranges from the Late Devonian to the Late Visean in England and is most abundant in the Etroeungtian $\mathrm{K}$ zone to the Tournaisian $\mathrm{Z}$ zone; Composita aff. C. argentea (SHEPARD) of Akiyoshi may be morphologically more primitive than C.argentea which first appears in the Lower Pennsylvanian of North America; Antiquatonia is known in post-Tournaisian Palaeozoic rocks and the type-species is from the Visean $D_{2}$ subzone in England; Dictyoclostus is common in the Carboniferous and Permian formations; Eomarginifera is known from the Visean of Europe and Asia and the Namurian of Europe.

Summarizing these evidances, it is concluded that the brachiopod-fauna of the "Uzura" quarry strongly suggests Medial to Late Visean age $\left(\mathrm{S}_{2} \sim \mathrm{D}_{3}\right)$ with a possibility of suggesting Late Visean $\left(D_{1} \sim D_{2}\right)$. 
Table 2. Chart showing the known ranges of the Akiyoshi species or their close affinities and the age of limestone of the "Uzura" quarry. A-A', possible; $B-B$ ', highly possible; •, close affinity.

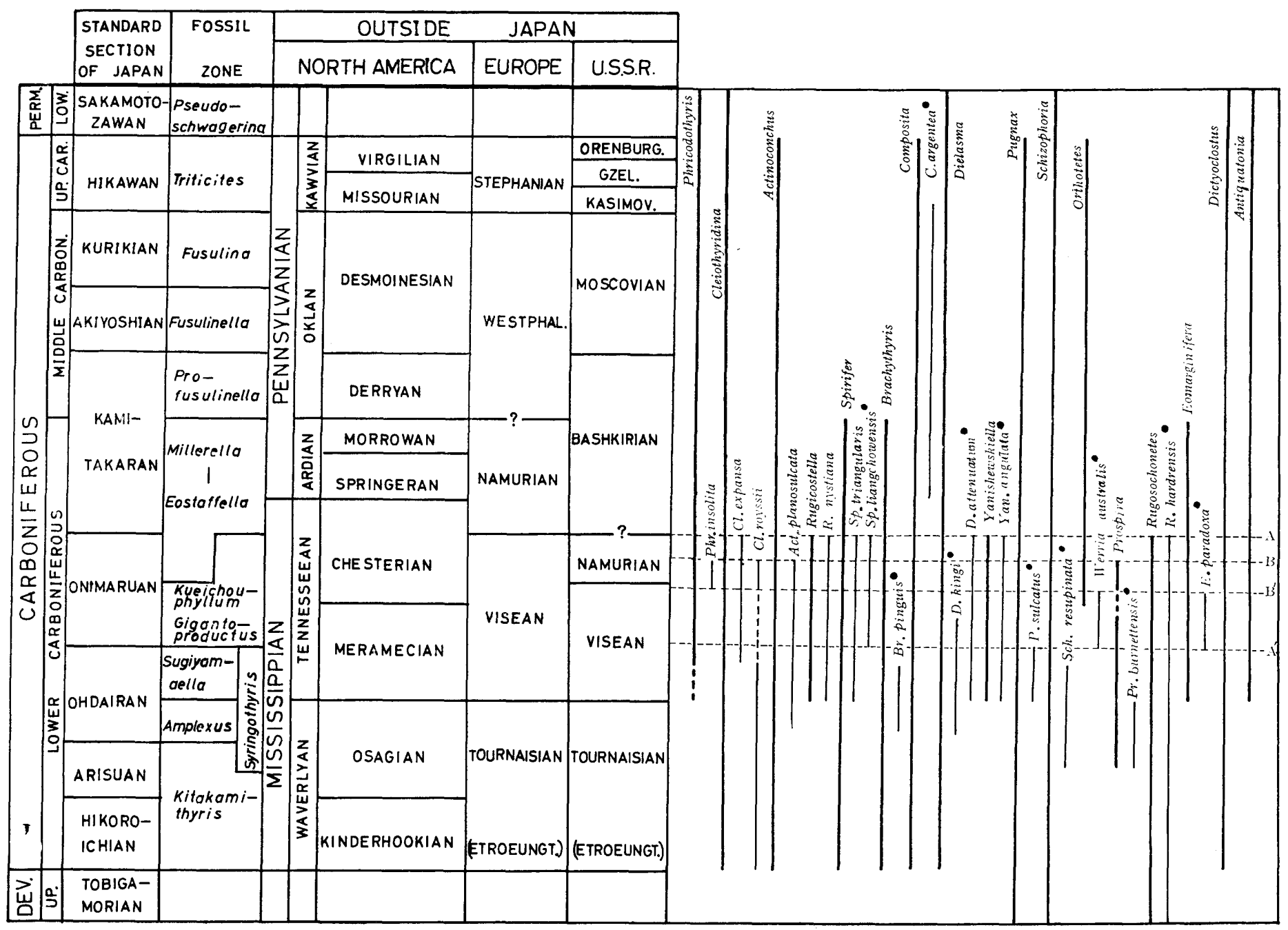




\section{Faunal affinities in Japan}

The Japanese Carboniferous brachiopods known are restricted to the Kitakami massif of Northeast Japan and the Hida massif of central Japan. The Visean brachiopods in them are reported from the Ohdaira and the Onimaru Formations of the Kitakami massif, and from the lowest formation of the Omi Limestone and the Hongo Formation of Hongo-Arakidani area of the Hida massif.

According to Minato et al. (1953), Onuki (1956), and Minato (1960), the Ohdaira Formation of about $700 \mathrm{~m}$ thick consists of pyroclastic rocks, alternations of slates and pyroclastic rocks, and sandstones. The formation was correlated to the Lower Visean mainly on the brachiopod faunas. The Ohdaira Formation is overlain unconformably by the Onimaru Formation of about $300 \mathrm{~m}$ thick. The Onimaru Formation is characterized by thick limestones and is correlated to the Upper Visean mainly on the many kinds of characteristic corals.

The first appearance of Millerella in the Onimaru Formation creates a problem. Minato (1960) subdivided the formation into a lower Hotokezaka subformation and an upper Hiishi subformation. He especially emphasized that the occurrence of Millerella is restricted to the latter. ONUKI (1956), on the other hand, correlated the Onimaru Formation to the zone of Millerella because of its occurence in the Takauchi limestone member, the lowest member of the formation.

The following brachiopods are described by Minato $(1951,1952)$ mainly from the lower and middle parts of the Ohdaira Formation: Cleiothyridina royssii (L'EveILLE), Spiriferina octoplicata Sowerby, Syringothyris transversa Minato, Syringothyris sp., Fusella nipponotrigonalis var. minor Minato, Brachythyris aff. B. pinguis (SowerbY), Brachythyrina nagaoi Minato. Five other species Productus sp. b, Pustula sp., Spirifer sp. c, Chonetes sp., Spirifer sp. d were also reported by Minato et al. (1953).

The following four species are known from the Onimaru Formation: Dictyoclostus sp., Gigantoproductus sp., Rhynchonella sp., Spirifer sp.. According to Minato et al. (1953), Gigantoproductus first appears in the base of the formation.

Comparing the Kitakami faunas with that of the Akiyoshi Cleiothyridina royssii from the Ohdaira Formation is the only species common to the Akiyoshi. Brachythyris and Spirifer are the only common genera to those of Akiyoshi. Fusella nipponotrigonalis of Kitakami may be related to "Spirifer" triangularis of Akiyoshi. Nothing is common among species of the Onimaru and the Akiyoshi faunas. Dictyoclostus and Spirifer of the former are only known from the latter.

The Omi Limestone of the Hida massif ranging from the Lower Carboniferous to the Middle Permian was first divided into several fossil zones by HAYASAKA (1924). KAWAdA (1954) and FuJITA (1958) revised the zonation and divided the Omi Limestone into five formations mainly based on the fusulinid zones. They are as follows in descending order respectively: $\mathrm{P}_{2}$ formation, Neoschwagerina zone; $\mathrm{P}_{1}$ formation, Pseudoschwagerina and Pseudofusulina zones; $\mathrm{C}_{3}$ formation, Triticites zone; $\mathrm{C}_{2}$ formation, Fusulinella zone; $\mathrm{C}_{1}$ formation.

Abundant corals and brachiopods occur in the lowest $\mathrm{C}_{1}$ formation and HAYASAKA (1924) correlated these faunas to those of the Tournaisian to Visean of Europe. 
Brachiopods consist of the following species: Gigantoproductus edelburgensis (PHILLIPS), Avonia cf. A. acculeata (MARTIN), Echinoconchus punctatus var., Productus semireticulatus MARTin, Camarophoria globulina PhILlips, Martinia glabra decora PHILliPs, Reticularia lineata MARTIN, R. elliptica PHILliPs, Syringothyris cuspidata (MARTIN). Productus (Dictyoclostus) is the only genus common to the Akiyoshi fauna and other genera are quite distinct from the Akiyoshi ones.

From the Arakigawa Formation of the Hongo-Arakigawa area, Fujimoto, KANUMA, and IGO (1962) reported the occurrences of Gigantoproductus sp. and Schizophoria? sp. associated with corals, bryozoans, and other fossils. They correlated the formation to the Lower to Upper Carboniferous.

As stated above, the Visean brachiopod-fauna which is in harmony with the Akiyoshi one has not been found in other districts of Japan. Cleiothyridina royssii, the same species both in Akiyoshi and Kitakami, has a long range in the Lower Carboniferous and is cosmopolitan in distribution. In the Kitakami Lower Tournaisian it is also reported from the Hikoroichi Formation. Other equivalent or related species of the Kitakami Carboniferous faunas to the Akiyoshi one are also characterized by those which have long ranges. They are Actinoconchus planosulcatus of the Hikoroichi Formation, Schizophoria resupinata of the Tournaisian Arisu Formation, and Chonetes hardrensis of the Etroeungtian Karaumedate Formation.

It is worthy of note that the Late Visean cosmopolitan Genus Gigantoproductus is common in the Onimaru Formation, the $\mathrm{C}_{1}$ formation of the Omi Limestone, and the Hongo Formation of the Hida massif. The genus Gigantoproductus shows its acme in the Visean $D_{2}$ subzone of the British Avonian and the equivalent sequences of Europe and Asia.

On the other hand, the Akiyoshi fauna is also characterized by representative Visean genera and species such as Phricodothyris insolita, Yanishewskiella japonica, Rugicostella nystiana, and "Spirifer" triangularis etc.. Therefore it is believed that the difference of Akiyoshi fauna and others may be caused by difference of the province or facies.

\section{Faunal affinities in other areas}

The Akiyoshi fauna has affinities with those of the Visean outside of Japan.

In Australia the Queensland Visean faunas (MAXWELL, 1954) are related to parts of the Akiyoshi one. Among them the Late Visean Spirifer cf. S. liangchowensis and Cleiothyridina transversa are respectively similar and compared with Spirifer aff. S. liangchowensis and Cleiothyridina expansa of Akiyoshi; Rugosochonetes, Phricodothyris, Prospira, and Brachythyris of Queensland are genera common to the Akiyoshi fauna. Queensland Late Tournaisian Prospira burnettensis is related to P. aff. P. burnettensis of Akiyoshi. Among the New South Wales Visean fauna (CAMPBELL, 1957) Eomarginifera paradoxa resembles Eomarginifera sp; Werriea australis is similar to Orthotetes sp; Schizophoria cf. S. resupinata is comparable with S. aff. S. resupinata; Rugosochonetes? werriensis is related to $R$. aff. $R$. hardrensis.

MAXWELL (1954) has pointed out that the paucity of productids in the Queensland Visean faunas is in harmony with that of Japan. This evidence is also acceptable 
in the Akiyoshi fauna in which productids are few and uniformly small.

In Malaya the Visean brachiopods described from the Kuantan district of Pahang, eastern Malaya by MUIR-Wood (1948) also have resemblance to the Akiyoshi ones. Among the Akiyoshi fauna Dielasma sp. is similar to Dielasma cf. D, attenuatum and Schizophoria aff.S. resupinata resembles Schizophoria sp.. Dictyoclostus, Brachythyris, Spirifer, Pugnax, Phricodothyris, and Cleiothyridina are common in the Akiyoshi genera. Spirifer sp. (striatus group), according to MUIR-Woon, may be closely related to $S$. liangchowensis of the Kansu Visean. However, the significant difference of the Malayan fauna to the Akiyoshi one is that the former contains many kinds of productid species among which some are in common to the fauna of northwest China and Yunnan,

It is interesting that the Akiyoshi fauna and that of the Chinese Visean Upper Fengninian have few affinities with each other and also there are no common species between the former and the Chinese Middle Carboniferous Penchian and Weiningian faunas. Cleiothyridina royssii of Hunan described by HAYASAKA (1922) is a common species in the Akiyoshi; Athyris submabranacea described by $\mathrm{CHU}$ (1933) from the Kinling Limestone is related to the Akiyoshi species Actinoconchus planosulcatus; Spirifer aff. S. liangchowensis of Akiyoshi is closely related to S. liangchowensis of the Visean Choniukou Formation of Kansu; Rugosochonetes aff. R. hardrensis is similar to Chonetes hardrensis var. kansuensis of the Choniukou Formation; Schizophoria aff. S. resupinata resembles S. resupinata of the Visean of Kansu and Hunan; Composita and Dielasma are common genera in the Akiyoshi. The Kansu and Hunan faunas are always associated with Gigantoproductus.

Among the Yunnan Carboniferous fauna, Composita cf. C. argentea and Schizophoria cf. S. resupinata respectively by GRABAU (1924) and REED (1927) are related to Composita aff. C. argentea and Schizophoria aff. S. resupinata of Akiyoshi.

Among the Visean fauna of Laos described by MANSUY (1913), Chonetes hardrensis and Schizophoria resupinata are closely related to Rugosochonetes aff. $R$. hardrensis and Schizophoria aff. S. resupinata of Akiyoshi respectively.

In Mongolia GRABAU (1924) recorded the occurrence of Schizophoria resupinata with other brachiopods including Gigantoproductus but a satisfactory correlation can not be made.

In Tien-Shan province in central Asia Visean faunas have been described by KRENKEL (1913), GRÖBER $(1908,1909)$ and other Russian and German authors. Among the Visean brachiopods Cleiothyridina expansa from Karkara and Mt. Khan Tengri, north and east Tien-Shan, and Cleiothyridina royssii from Mt. Khan Tengri have their equivalents in the Akiyoshi fauna. Schizophoria resupinata from Bash-Sugun, Chinese Turkestan, and Chodzchur-noe-ussun, east Tien-Shan and Rugosochonetes hardrensis from the latter are closely related to Schizophoria aff. S. resupinata and Rugosochonetes aff. R. hardrensis of Akiyoshi. A peculiar occurrence is Yanishewskiella angulata from Basch-Sugun, which is represented in Akiyoshi by closely related Yanishewskiella japonica. Pugnax, Dielasma, Spirifer, and Dictyoclostus are genera common to the Akiyoshi fauna.

In Ferghana, farther west of Tien-Shan, Visean faunas have been described by 
many Russian authors. The following species described by YANISHEWSKY (1918) are common to the Akiyoshi fauna; Actinoconchus planosulcatus, Spirifer triangularis, Cleiothyridina expansa. The following is closely related to the Akiyoshi species; Schizophoria resupinata resembles S. aff. S. resupinata, Yanishewskiella angulata is closely similar to $Y$. japonica, and Rugosochonetes hardrensis is related to $R$. aff. $R$. hardrensis. Dielasma sp. of Akiyoshi resembles Dielasma attenuatum of the Ferghana Visean. A difference of the Ferghana fauna from the Akiyoshi one is abundant occurrence of productid species including Gigantoproductus giganteus.

The following species the same or closely related to Akiyoshi ones are known in the Visean of the Donetz basin: Spirifer triangularis, Schizophoria resupinata, Cleiothyridina royssii, Rugosochonetes hardrensis. These brachiopods are associated with Gigantoproductus giganteus. In Siberia Rugosochonetes hardrensis and Mucrospirifer sp. respectively from the Upper Tournaisian and Upper Visean to Namurian of the Kuznetzk coal basin (SARYTCHEVA et al., 1963) are closely related to Rugosochonetes aff. R. hardrensis and "Spirifer" triangularis of Akiyoshi.

The Visean of western Europe has many species in common with the Akiyoshi fauna. The characteristic Visean species recognized in the Akiyoshi fauna are the followings; Cleiothyridina expansa, Phricodothyris insolita, Actinoconchus planosulcatus, Rugicostella nystiana, and Spirifer triangularis. Yanishewskiella japonica and Pugnax aff. $P$. sulcatus have respectively closely related species $Y$. angulata and Pugnax sulcatus in the Visean of western Europe.

An American Pennsylvanian species Composita argentea is only related to Composita aff. C. argentea of Akiyoshi.

In summary, it is concluded that the Akiyoshi fauna consists of a number of cosmopolitan genera and some regional ones. It has a close relation to that of the Queensland Visean of Australia. The remarkable paucity of productid species in the Akiyoshi fauna is also in harmony with that of the latter. The Malayan fauna and the Akiyoshi one are not considered to be closely related because of the absence of the common species, the paucity of related ones, and the predominance of productid genera in the Malayan fauna. The same characters observed in the Malayan fauna are also recognized in the Fenningian fauna of south China. The disharmony of faunas of Akiyoshi and south China may be due to the difference of facies of both provinces. The Akiyoshi fauna, on the other hand, has a close relation to the Visean fauna of Kansu, northwest China. Moreover, farther west of Kansu, it is interesting to note the occurrence of Yanishewskiella continuously from Akiyoshi to western Europe through Tien-Shan, Ferghana, and Ural. Also the new occurrence of Rugicostella hitherto only known from the Visean of Belgium and England suggests that the sea at that time extended from western Europe to Akiyoshi through central Asia and northwest China. Also the sea was immediately connected with that of northeastern Australia in Visean time.

\section{On the age of the "Uzura" limestone}

Some opinions have been published on the age of the lower part of the Akiyoshi 
limestone Group on different data, especially from the lowest up to the zone of Millerella. These are represented by those of Minato and KATo (1957, 1963), and HASEGAWA (1958, 1963), which the lowest part of the Akiyoshi limestone Group is correlated to the Lowest Namurian. On the contrary, MURATA (1961) and OKimurA (1963) correlated the lowest horizon of the limestone group to the Lower Carboniferous. The former opinions are mainly based on the zone of coral and the latter on zones of fusulinids and smaller foraminifers. The correlation of each division of their fossil zones are as follows.

\begin{tabular}{c|l|c}
\hline Murata (1961) & \multicolumn{1}{|c|}{ Onimura (1963) } & $\begin{array}{c}\text { Hasegawa (1963), } \\
\text { Minato and Kato (1963) }\end{array}$ \\
\hline Profusulinella zone & Profusulinella beppensis zone & Profusulinella zone \\
\hline \multirow{2}{*}{ Millerella zone } & Pseudostaffella sp. A zone & Millerella zone \\
\cline { 2 - 3 } & Millerella sp. A zone & \\
\hline \multirow{2}{*}{ Endothyra zone } & Pseudoendothyra spiroides zone & Nagatophyllum zone \\
\cline { 2 - 3 } & Endothyra sp. A zone & \\
\hline
\end{tabular}

MuRATa has drawn the boundary of the Visean and Namurian in the lower part of the Millerella zone andOKimura considered it to be at the base of his Millerella sp. A zone.

Brachiopod-fauna from the "Uzura" limestone shows the close alliance to the Upper Visean faunas of Europe, Asia, and Australia. Among the fossils besides brachiopods YAMAGIWA and OTA (1963) described the following corals which are well preserved in the limestone: Stylidophyllum ozawae YAMAGIWA and OTA, Clisiophyllum awa (Minato), Clisiophyllum sp. indet., Lonsdaleoides toriyamai Minato, Lophophyllidium uzurensis YAMAGIWA and OTA. In addition to these species I confirmed the occurrence of Nagatophyllum cf. N. satoi OzAWA in association with them. Considering these corals, the following ranges of each are recognizable. Clisiophyllum awa occurs in Southwest Japan from the zone of Pseudoendothyra spiroides of Atetsu Limestone (OKImURA, 1958), Okayama Prefecture, up to the zone of Fusulinella of Omi Limestone, Niigata Prefecture. Lonsdaleoides toriyamai occurs from the zone of Millerella to. the zone of Profusulinella in Akiyoshi and Taishaku, western Chugoku. Stylidophyllum ozawae and Lophophyllidium uzurensis are only known in the "Uzura" limestone but the genera are known from the Lower to the Middle Carboniferous and from the Pennsylvanian to the Permian, respectively. The occurrence of Nagatophyllum satoi is restricted in western Chugoku and southwestern part of the Hida massif. Such being the case it is difficult to confirm the age of the "Uzura" limestone from these corals because they have relatively long ranges.

OKIMURA (1963) established five foraminiferal zones on the limestone underlying Profusulinella zone of the Akiyoshi limestone Group and correlated them to those of the Atetsu Limestone of Okayama Prefecture. They are as follows in descending order: the Profusulinella beppensis zone, the Pseudostaffela sp. A zone, the Millerella 
sp. A zone, the Pseudoendothyra spiroides zone, and the Endothyra sp. A zone. OKImurA correlated the Millerella zone to the Lower Bashkirian and considered that the Pseudoendothyra spiroides and Endothyra sp. A zones may be Lower Carboniferous respectively. The foraminiferal fauna of the Millerella sp. A zone, according to OKIMURA, shows the closest affinity to that of the Upper Visean of Sikhotealin. But abundant occurrences of Ozawainella and Globivalvulina, representative genera of Sikhotealin Bashkirian, in the Millerella sp. A zone confirm its correlation to the Lower Bashkirian.

When I reflect upon the foraminiferal fauna of the "Uzura" limestone, the following facts seem clear. It contains Millerella and Eostaffella most abundantly, and a number of Pseudoendothyra and Plectogyra are also associated. A few Glomospira and Granulifella also occur. Ozawainella is not found at all. Summing up the foraminiferal fauna of the "Uzura" limestone, it is characterized by the Upper Visean elements for the most part. Although a problem remains on the relation of lithofacies and fauna, the limestone hardly correlates to the Lower Bashkirian on the above assemblage. This is also supported by a relatively large occurrence of individuals of Eostaffella and Pseudoendothyra among the foraminiferal genera. The "Uzura" quarry is located about $7 \mathrm{~km}$ west of the southern margin of the Akiyoshi limestone plateau where OKIMURA dealt with his foraminiferal zones. It is impossible to know the relation of both limestone. But it is believed that a horizon which is absolutely lacking in Ozawainella and contains smaller foraminifers similar to those of the Pseudoendothyra spiroides zone will exist in the lower part of OKImURA's Millerella sp. A zone.

According to Murata (1961) the lower part of the Millerella zone of the Akiyoshi limestone Group is characterized by Millerella komatui IGo and M. uzurensis MURATA (M. S.). The former was originally described by Igo (1957) from the Ichinotani Formation of Fukuji, Gifu Prefecture. In Fukuji it is associated with Millerella kanmerai IGo and also abundant corals such as Siphonodendron, Dibunophyllum, Kueichouphyllum, Clisaxophyllum, Hexaphyllia, and Neokoninckophyllum. Most of these corals are representatives of the Upper Visean.

Minato (1960) considered that the Millerella kanmerai subzone of Fukuji is older than the Nagatophyllum satoi subzone (=Nagatophyllum zone, 1963) of Akiyoshi and the lowest part of the subzone is correlative to the Hiishi Stage, the upper half of the Onimaru Formation of Kitakami massif, from the coral fauna. According to Minato, those formations which were characterized by the coral faunas of the lower half of the Stylidophyllum sp. subzone (= Millerella zone, 1963) and the Nagatophyllum satoi subzone of the Akiyoshi limestone Group widely distribute in the Taishaku, Ibuki, and Omi districts of Southwest Japan, and they are distinctly correlative to the Sabukura Stage, the lower half of the Nagaiwa Formation. He concluded their age to the Lowest Pennsylvanian. The basis of his correlation is that the representative corals of the Nagatophyllum zone are unknown in the Upper Visean Onimaru Formation and its equivalents widely distributed in Japan and that among the coral faunas of Nagatophyllum satoi and Stylidophyllum sp. subzones the Late Visean corals never occur. 
I have some doubts about Minato's opinions. Corals which form the subzones of Nagatophyllum satoi and Stylidophyllum sp. of MinATo and KATO (1957) respectively have long ranges in Southwest Japan as they were studied more in detail in relation to the zones of fusulinids. But the relation of the Millerella zone to the Nagatophyllum zone is not clear in Akiyoshi. The ranges of those characteristic corals of Southwest Japan must be clarified in detail with a possibility of their first appearance extending to the Lower Carboniferous. For instance OKIMURA (1958) recorded the occurrence of Hexaphyllia sp., Siphonodendron sp., Amygdalophyllum giganteum (YABE and HAYASAKA) associating with Clissiophyllum awa MinAto, Cl. awa atetsuense Minato and NAKAzAW A, and Stylidophyllum sp. from a lower horizon of the Endothyra spiroides zone (=Pseudoendothyra spiroides zone, 1963) in the Nagoe Formation of the Atetsu limestone, Okayoma Prefecture. Haxaphyllia and Siphondendron are the representative corals of the Onimaru Formation of Kitakami. Amygdalophyllum giganteum was originally described from the Omi limestone in association with many brachiopods and corals most of which were compared with the fauna of the Onimaru Formation. This is a very important fact although it is only evidence of co-occurrence of faunal elements of the Onimaru Formation and subzones of Nagatophyllum satoi and Stylidophyllum sp. of Akiyoshi. It is considered that the independence of coral faunas in the Kamitakaran Epoch recognized between the Carboniferous of the Inner zone of Southwest Japan and Northeast Japan had already begun in the Onimaruan.

HASEGAWA (1963) reported the occurrence of brachiopods and corals from reddish tuffaceous shale near the lowest part of the Akiyoshi limestone Group. Minato and KATO (1963) described them and discussed their age. The discovery of these fossils is very important. Because the lower part of the Akiyoshi limestone Group is always characterized by reddish tuffaceous shale or pyroclastic rocks. Therefore if the faunal age is confirmed, the geological age of the lowest part of the Akiyoshi limestone Group is firmly recognized. Minato and Kato distinguished the following corals and brachiopods: Cyathaxonia sp., Pleurodictym dechenianum KAYser, Schuchertella sp. a, Schuchertella sp. b, Chonetes sp., Waagenoconcha sp., Neophricodothyris? sp., and Nebenothyris hasegawai MinATo and KATO. It seems to be difficult to adequately conclude the age of the fauna from these elements. But they regarded it to be Lowest Namurian. According to them, the reddish tuffaceous shale is overlain by the limestone of the Nagatophyllum zone and elements of the Upper Visean Onimaru fauna are lacking. Therefore the Akiyoshi fauna is younger than the Late Visean. However, their conclusions are hardly acceptable, because they laid more stress on the relation of the tuffaceous shale to the limestone of the Nagatophyllum zone than discussing the species assemblage. This has less meaning for establishing the age than discussing the fauna itself. Moreover it is doubtful that the Akiyoshi fauna is younger than the Onimaru fauna because of lack of the elements of the latter in the former. I consider that assignment of the Akiyoshi fauna to the Earliest Namurian from this assemblage of species is untenable.

Recently I obtained many specimens of brachiopods from the reddish tuffaceous shale to clarify their age. The following species were distinguished: Rhynchopora sp., Setigerites sp., Werriea cf. W. australis CAMPBELL, Schuchertella spp., Orbinaria 
sp., Eomarginifera aff. E. paradoxa (CAMPBELL), and Quadratia sp..

This brachiopod-asssemblage was too poorly preserved to know the detailed characters. But the following are valid for age determination of the assemblage: Setigerites sp., Werriea cf. W. australis CAMPBELL, Eomarginifera aff. E. paradoxa (CAMPBELL), Oribinaria sp., Quadratia sp.. Setigerites is known from the Osage and the Meramec Group of North America and from the Middle Tournaisian $\left(\mathrm{C}_{1}^{t} \mathrm{td}\right)$ to the Lower Visean $\left(\mathrm{C}_{1}^{v} \mathrm{pd}\right)$ of the Kuznetzk Basin of Russia. Werriea cf. W. australis is closely comparable to $W$. australis of the Lower Carboniferous of Babinboon, New South Wales (CAMPBELL, 1957). Eomarginifera aff. E. paradoxa is also closely related to E. paradoxa which is associated with Werriea australis in New South Wales. Eomarginifera ranges from the Visean up to the Namurian and is cosmopolitan in Visean time. Australian species were first compared by CAMPBELL with those of North America and were recorded as Upper Tournaisian. But, according to his personal communication from CAMPBELL, the age of the fauna must be revised to Medial Visean because of emendation of the age of the American fauna to which he correlated it.

Quadratia sp. and Orbinaria sp. are poorly preserved but the genera are known from the Mississippian of North America.

Rhynchopora and Schuchertella have long ranges from the Lower Carboniferous up to the Permian. Detailed comparison of the species with others is difficult because of poor preservation of the specimens.

These materials are not enough to determine their exact age, however, it is. difficult to date them as Namurian.

The following important facts were added to the above evidence. From the oolitic limestone, partly clastic and tuffaceous, about $10 \mathrm{~m}$ below the reddish tuffaceous shale the following brachiopods, and corals were obtained with bryozoans, smaller foraminifers, and crinoid ossicles; Syringothyris spp., Schizophoria cf. S. resupinata, Leptagonia sp., Spirifer spp., Zaphrentoides sp., and Cyathaxonia sp*. The oolitic limestone conformably underlies the reddish tuffaceous shale.

Syringothyris is one of the leading fossils of the Lower Carboniferous. In Europe it is abundant in the Tournaisian and the Lower Visean showing its climax in the $\mathrm{C}$ zone in the English Avonian. In North America Syringothyris is known from the Kinderhookian up to the Meramecian. In Russia it is known from the Upper Tournaisian $\left(\mathrm{C}_{1}^{t} \mathrm{nt}\right)$ up to the Lower Visean $\left(\mathrm{C}_{1}^{n} \mathrm{pd}\right)$ and is most abundant in the Upper Tournaisian. In Japan it is known from the $C_{1}$ zone of the Omi Limestone and the Lower Carboniferous of the Kitakami massif. Kitakami Syringothyris ranges from the uppermost Hikoroichi Formation up to the lower Ohdaira Formation, and it is most abundant in the Upper Tournaisian Arisu Formation. Leptagonia is known from the Lower Devonian up to the Lower Carboniferous. Schizophoria ranges from the Silurian up to the Permian and is cosmopolitan in the Lower Carboniferous. Zaphrentoides is one of the index fossils of the Lower Carboniferous and a repre-

* YANAGIDa and OTA, read at the 71st annual meeting of the Geological Society of Japan, April, 1964. 
sentative of "Zaphrentis" zone of English Avonian. Cyathaxonia is also a representative genus of the Lower Carboniferous of North America, Europe, Australia and Asia.

The assemblage of these brachiopods and corals apparently indicates the Lower Carboniferous. Although palaeontological study of them has not been sufficiently carried out the species assemblage shows the age of the Late Tournaisian to the Early Visean.

The following conclusions are apparent from this evidence. The age of the limestone which contains brachiopods and corals such as Syringothyris, Spirifer, Cyathaxonia and Zaphrentoides is Late Tournaisian or Early Visean. Reddish tuffaceous shale which conformably overlies the limestone and contains numerous brachiopods may be Early to Medial Visean in age.

Strict correlation of the lower part of the Akiyoshi limestone Group with other Carboniferous formations in Japan is difficult. In the Kitakami massif pyroclastic rocks begin to predominate below the middle part of the Lower Visean Ohdaira Formation. It is interesting that the Omi Limestone also has pyroclastic rock in the lowest part of the $C_{1}$ zone in association with sandstone and shale. Pyroclastic rocks are also recognized in the lower part of the Carboniferous formations of Taishaku, Hiroshima Prefecture and Atetsu of Okayama Prefecture.

With regard to the age of the lowest part of the Akiyoshi limestone Group I consider the age of the "Uzura" limestone to Late or Latest Visean. This is supported stratigraphically by the faunal assemblage of brachiopods and foraminifers. The Namurian in the Akiyoshi limestone Group lies at a higher horizon than that of the "Uzura" limestone. In relation to this problem it is worthy to note the existence of the Pseudostaffella sp. A zone over the Millerella sp. A zone. According to OKIMURA (1963), Pseudostaffella sp. A zone mainly consists of Pseudostaffella, Ozawainella, Millerella, and Endothyra but never contains Profusulinella.

\section{Concluding Remarks}

With the aid of biostratigraphy of the part underlying the Millerella sp. $\alpha$ zone of the Akiyoshi limestone Group, many kinds of brachiopods of the "Uzura" limestone which also contains abundant corals, fusulinids, and other smaller foraminifers were studied. Materials dealt with were restricted to a horizon and therefore successive change of faunas with age remained a problem. However, a number of brachiopods are sufficient to determine the age and affinities with other faunas in other districts. As brachiopods and other fossils from underlying parts of the "Uzura" limestone come to hand, further detailed palaeontological and stratigraphical studies will be possible in the near future.

A summary of this study follows. Brachiopods of the "Uzura" limestone mainly consist of Medial or Late Visean elements. It is believed that the age of the fauna is from the Medial to the Late Visean with a high possibility of the Late Visean. Associated fusulinids and other smaller foraminifers also support the age determined by the brachiopod fauna. 
Regarding the relation with the Late Visean brachiopods of other districts of Japan I can not recognize any common species with the Akiyoshi one in the Onimaru Formation of the Kitakami massif and Omi Limestone of central Japan. Gigantoproductus recorded from these localities was not found in Akiyoshi. Adding the above evidence, productids from Akiyoshi are all extremely small and very few in numbers and kinds.

The Akiyoshi fauna has close alliances in northwest China, Tien Shan, Ferghana, Kuznetzk, and further west to Donetz, western Europe, and England. Species common to or closely allied with the Akiyoshi ones are often recognized in these districts and genera which are only known in some of these provinces are also found in the "Uzura" limestone. Therefore it is considered that the geosynclinal sea in Visean time developed in these European and Asiatic regions immediately extended further east to Japan and the migration of faunas accomplished.

On the other hand, I can recognize a close relation of species of the Akiyoshi fauna with those of the Visean faunas of eastern Australia. It is true that Japan and Australia were connected with each other in Visean time. It is not sure that both regions were immediately connected by a geosynclinal sea across the present ocean at that time. It is interesting that the Visean faunas of southern China and Malaya show less similarity to the Akiyoshi one than to the Australian faunas.

Regarding the species assemblage of corals with brachiopods there is a problem for the definite geological age of "Nagatophyllum fauna". It is clear that the following species of Stylidophyllum ozawae, Clissiophyllum awa, Lonsdaleoides toriyamai, Lophophyllidium uzurensis, and Nagatophyllum cf. N. satoi from the "Uzura" limestone respectively have longer stratigraphic ranges downward to the Late Visean than those hitherto known. It is necessary to know accurate ranges and stratigraphic position of these Carboniferous corals in the Akiyoshi limestone Group.

It is clear that the "Kueichouphyllum sea" of Minato (1953) characterized by Kueickouphyllum, Dibunophyllum, and other corals is distinguished on its biofacies from the sedimentary province characterized by Nagatophyllum satoi, Clissiophyllum awa, and other corals. The former is represented in Japan by the Upper Visean Onimaru Formation of the Kitakami massif and its equivalents of Abukuma, Hida, and Kyushu. On the other hand, the latter province is represented by Akiyoshi, Taishaku, Atetsu, Otaki, and Omi districts disposing on the Inner zone of Southwest Japan.

The Late Visean sea in Japan was composed of two different faunal provinces. One was strongly connected with that of southern China but the other was related to that of northwest China to Europe. It is unknown whether a certain barrier was spread between those different faunal provinces or not. However, it is very interesting that the difference of faunas is related to the difference of the sedimentary facies between them. The Lower Carboniferous limestone of the inner zone of Southwest Japan is generally light grey to white, massive, very thick, and very pure, and is characterized by the Nagatophyllum and Clisiophyllum fauna. While the limestones of the outer zone of Southwest Japan and Northeast Japan are commonly dark grey, muddy, and often intercalate black slates, sandstones, pyroclastic rocks, and cherts, and are represented by the Kueichouphyllum fauna. An exception is the Ichinotani Formation of the Hida massif. It is near the Omi Limestone and 


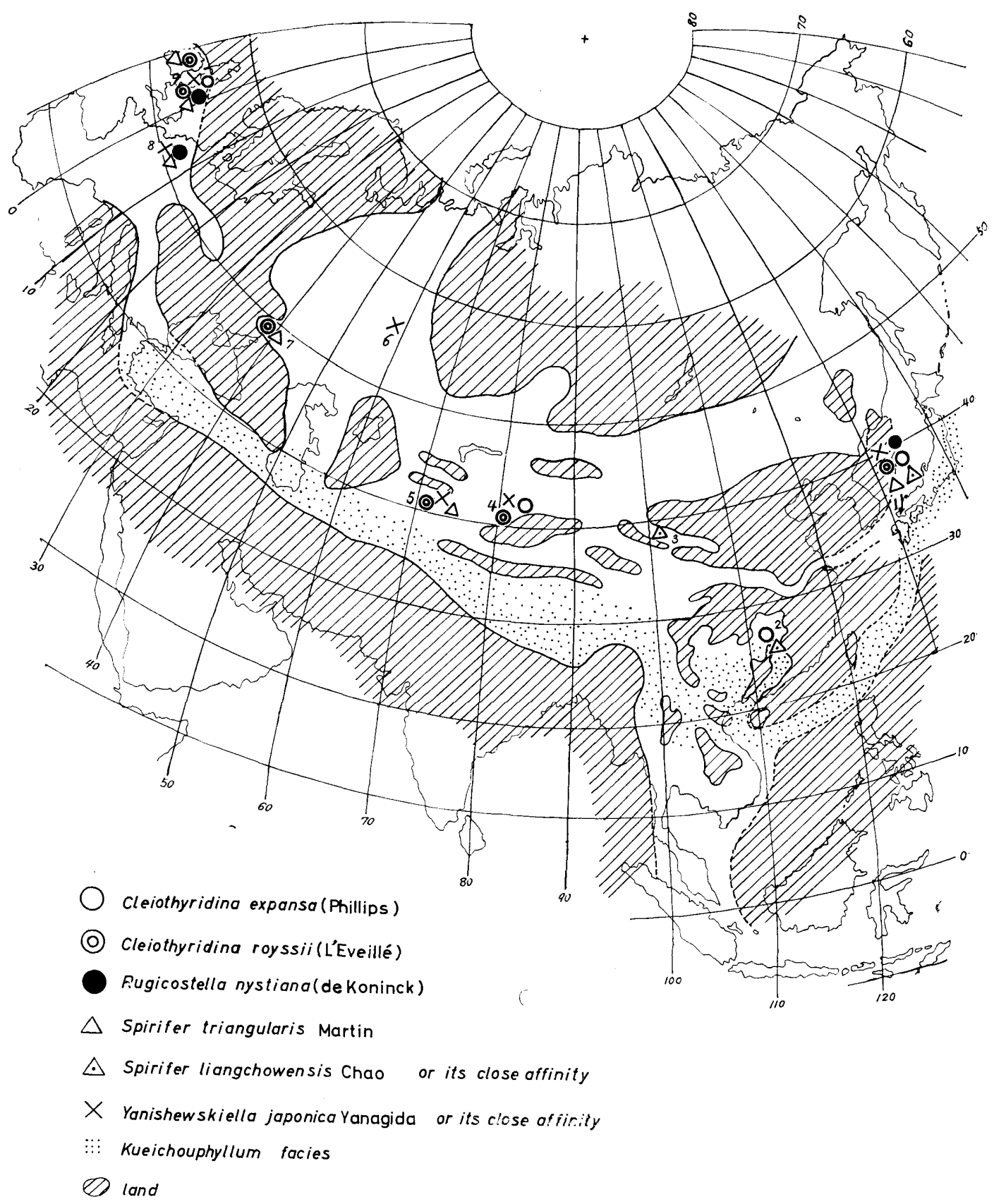

Fig. 5. Visean palaeogeography of Eurasia (Compiled after Muir-Wood, 1948; Minato, 1953; Liu, 1955 and Hamada, 1960, etc.) and distributions of some representative species of brachiopods or their close affinities of Akiyoshi. 1: Akiyoshi, 2: Central Hunan, 3: Northwest Kansu, 4: Tien-shan, 5: Ferghana, 6: Ural Mountains, 7: Donetz Basin, 8: Belgium, 9: Great Britain and Ireland. 
in the Inner zone of Southwest Japan. It is characterized by impure limestone and the Kueichouphyllum fauna.

The age and correlation of the lowest part of each limestone formation distributed in Akiyoshi, Taishaku Oga, Atetsu, and Omi, from the west to the east of the Inner zone of Southwest Japan, must be confirmed. These limestone formations characteristically have a considerable amount of pyroclastic rocks near their lowest part. For the purpose of clarifying the faunal difference between the Lower Carboniferous of the inner zone of Southwest Japan and others, it is necessary to establish the characteristics of each faunal province and relation between them. It is also very important to make a detailed stratigraphical and petrographical study of the thick, noncalcareous sedimentary rocks which are distributed in the circumference of the limestone plateau of the inner zone of Southwest Japan ranging from the Carboniferous to the Upper Permian.

\section{Acknowledgements}

I wish to express my sincere appreciation to Professor Ryuzo TORIYAMA of Kyushu University for his kindness in reading the manuscript and giving me advice and suggestions. Special thanks are due to Assistant Professor Kametoshi Kanmera and Professor Tatsuro MATsumoto for their valuable criticisms and continued encouragements for my study.

I am deeply indebted to Dr. G. A. Cooper of the Smithsonian Institution, who has critically read the typescript and given me valuable suggestions.

Sincere appreciation is acknowledged to Mr. Masamichi OTA of Akiyoshi-dai Science Museum for his valuable discussions and his kind help in giving me every facility for my field-work. I am also indebted to Messrs. Takesi AkATsu and Masao NAKAmura of Yawata Chemical Industry Co., Ltd., for their kind help in chemical anaiysis.

\section{References cited}

Armstrong, A.K. (1962): Stratigraphy and paleontology of the Mississippian System in southwestern New Mexico and adjacent southeastern Arizona. New Mexico Bureau of Mines, Mem., 8, 1-69, 12 pls.

БЕзносова Г.А. (1959): Нижнекаменноугольные брахиоподы кузнецкого бассейна (семейства Cyrtospiriferidae и Spiriferidae). ТРуды Палеонт. ИНСт. АНСССР, 75, 1-131, 11 Табл.

Buckman, S.S. (1906) : Brachiopod nomenclature. Ann. Mag. Nat. Hist., [7], 58, 321-327.

CAmpbell, K.S.W. (1953) : The fauna of the Permo-Carboniferous Ingelara beds of Queensland. Publ. Univ. Qld. Dep. Geol., 4, (3), 1-30, 7 pls.

(1954): The genus Phricodothyris in the Carboniferous of New South Wales. Geol. Mag., 92, 374-384, 1 pl.

- (1957) : A Lower Carboniferous brachiopod-coral fauna from New South Wales. Jour. Paleont., 31, (1), 34-98, 7 pls.

- (1961): Carboniferous fossils from the Kuttung rocks of New south Wales. Palaeontology, 4, (3), 428-474, 11 pls.

Chao, Y.T. (1927): Productidae of China. Part 1, Palaeont. Sinica, [B], 5, (2), 1-192, 16 pls. (1928 a): Productidae of China. Part 2, Ibid., [B], 5, (3), 1-79, 6 pls. 
(1928 b) : Carboniferous and Permian spiriferids of China. Ibid., [B], 11, (1), 1-104, 11 pls.

CHU, S. (1933): Corals and brachiopods of the Kinlin Limestone. Mon. Nat. Res. Inst. Geol., $[\mathrm{A}], 2,1-58,5$ pls.

Davidson, T. (1858): A monograph of British Carboniferous brachiopoda. Palaeont. Soc., Mon. Brit. Foss. Brach., 2, (5), 1-280, 55 pls.

Dunbar, C.O. and Condra, G.E. (1932) : Brachiopoda of the Pennsylvanian System in Nebraska. Bull. Nebraska Geo. Surv., 5, 1-377, 44 pls.

EAston, W.H. (1962): Carboniferous formations and faunas of central Montana. U.S. Geol. Surv. Prof. Paper, 348, 1-126, 11 pls.

Fujimoto, Haruyoshi (Editor) (1960): Carboniferous System of Japan. Geol. Surv. Japan, special report (D), 1-65.

Fujimoto, Haruyoshi, Kanuma, Mosaburo, and Igo, Hisayoshi (1962): Upper Palaeozoic formations of the Hida massif. (in Japanese with English abstract). Publ. Geologic Research of the Hida Massif, 44-70.

Fujita, Hiroshi (1958): Geology of the Omi Limestone (Permo-Carboniferous), Niigata Prefecture (in Japanese with English abstract). Contr. Inst. Geol. Palaeont., Tohoku Univ., (48), 1-60.

George, T.N. (1927): Studies in Avonian brachiopoda. I, The genera Brachythyris and Martinia. II, The genus Camarophoria. Geol. Mag., 64, 106-119, 193-201.

(1932): The British Carboniferous reticulate spiriferidae. Quart. Jour. Geol. Soc., $88,516-575,5$ pls.

Grabau, A.W. (1924): Stratigraphy of China. Geol. Surv. China, part 1, 1-528, 6 pls. (1932): Problems in Chinese stratigraphy. Sci. Quart. Nat. Univ. Peking, 2, (4), 423479.

Hamada, Takashi (1960): Some Permo-Carboniferous fossils from Thailand. Sci. Pap. Coll. Gen. Education, Univ. Tokyo, 10, (2), 337-361, 2 pls.

Hasegawa, Yoshiyuki (1958): Note on the geological structute of the Akiyoshi plateau, s.w. Honshu (in Japanese with Eiglish abstract). Earth Science, (39), 15-18.

(1963): New find of fossils in the reddish tuffaceous shale in the Akiyoshi province. Ibid., (64), 32-37.

HAYASAKA, Ichiro (1922): Palaeozonic brachiopoda from Japan, Korea and China. Part I, Middle and southern China. Sci. Rep. Tohoku Univ., [2], 8, (1), 1-83, 7 pls.

- (1924): On the fauna of the anthracolithic limestone of Omi-mura in the western part of Echigo, Ibid., [2], 8, (1), 1-83, 7 pls.

Igo, Hisayoshi (1956): On the Carboniferous and Permian of the Fukuji district Hida massif, with special reference to the fusulinids zone of the Ichinotani Group (in Japanese with English abstract). Jour Geol. Soc. Japan, 62, (728), 217-240.

- (1957): Fusulinids of Fukuji, southeastern part of the Hida massif, central Japan. Sci. Rep. Tokyo Kyoiku Daigaku, [c], 5, (47), 153-246, 15 pls.

Kanmera, Kametoshi (1952): The Lower Carboniferous Kakisako Formation of southern Kyushu, with a description of some corals and fusulinids. Mem. Fac. Sci. Kyushu Univ., [D], 3. (4), 157-177, 5 pls.

KAWADA, Sigema (1954 a): Stratigraphycal and palaeontological studies of the Omi Limestone in the Itagamine district, Niigata Prefecture (in Japanese with English abstract). Tokyo Univ. Education, Stud. Geol. Min. Inst., (3), 15-27.

- 1954 b) : Stratigraphical and palaeontological studies of the Omi Limestone in the Mt. Kurohime district, Niigata Prefecture (in Japanese with English abstract). Misc. Rep. Inst. Nat. Resources, 35, 48-56.

Koninck, L. (1887): Faune de calcaire carbonifere de la Belgique. Ann. Mus. Roy. Hist. Nat. Belgique, 45, (6), 1-154, 31 pls.

Konishi, Kenji (1963): Pre-Miocene basement complex of Okinawa, and the tectonic belts of the Ryukyu Islands. Sci. Rep. Kanazawa Univ., 8, (2), 569-602.

Licharew, B. (1936): The interior structure of Camarophoria King. Am. Jour.Sci., 32, (187), 
55-69.

Лихарев, Б. К. (1957): О роде Goniophoria YАN. и о других близких к нему родах. ЕЖЕГОдН. Палеонт. ОБщестьа, 16, 134-141.

Mansuy, H. (1913): Nouvelle contribution á la paleontologie de l'Indochine. II, Faune du Carboniférien inférieur de Tran-ninh. Mém. Serv. Géol. Indochine, 2, (5), 30-33, 2 pls.

Maxwell, W.G.H. (1951) : Upper Devonian and Middle Carboniferous brachiopods of Queensland. Publ. Univ. Qld. Dep. Geol., 3, (14), 1-27, 4 pls.

(1954): Upper Palaeozoic formation in the Mt. Morgan district-faunas. Ibid., 4, (5), $1-58,5$ pls.

(1960): Tournaisian brachiopods from Baywulla, Queensland. Ibid. 5, (8), 1-9, 1 pl. (1961): Lower Carboniferous brachiopod faunas from Old Cannindah, Queensland. Jour. Paleont., 35, (1), 82-103, 2 pls.

Minato, Masao (1951): On the Lower Carboniferous fossils of the Kitakami massif, northeast Honshu, Japan. Jour. Fac. Sci. Hokkaido Univ., [4], 7, (4), 355-372, 5 pls.

(1952): A further note on the Lower Carboniferous fossils of the Kitakami mountainland, northeast Japan. Ibid., [4], 8, (2), 146-174, 11 pls.

Minato, Masao, Hashimoto, Seiji, Suyama, Kunio, Takeda, Hiroyuki, Suzuki, Yoshio, Kimura, Shoji, Yamada, Kazuo, Kakimi, Toshihiro, Ichikawa, Teruo, and Suetomi, Hiroshi (1953): Biostratigraphie des Karbons in Kitakami Gebirge, nordoestliches Honshu, Japan (in Japanese with German abstract). Jour. Geol. Soc, Japan, 59, (695), 385-399.

Minato, Masao (1953): Palaeogeographie des Karbons in Ostasien. Proc. Japan Acad., 28, 246-253.

- (1956): Palaeogeography of the Japanese islands and their adjacent lands in the Upper Palaeozoic Era (in Japanese with English abstract). Earth Science, (28), 1-13.

Minato, Masao and Kato, Makoto (1957 a): On the Carboniferous coral zones in the Akiyoshi plateau, southwest Japan. Proc. Japan Acad., 33, (9), 541-546.

(1957 b): On the Carboniferous coral zones at Fukuji, Gifu Prefecture, central Japan. Ibid., 33, (9), 547-552.

Minato, Masao (1960): The boundary between the Lower and Upper Carboniferous in Japan. Amer. Jour. Sci., 258, 637-663.

Minato, Masao and Kato, Makoto (1963): Fossils with the Lowest Namurian aspect newly found by Dr. Y. Hasegawa in the Akiyoshi province. Earth Science, (66), 32-42, 2 pls.

Muir-Wood, H. (1929): The classification of the British Carboniferous brachiopod subfamily productinae. Ann. Mag. Nat. Hist., 5, 100-108.

(1948): Malayan Lower Carboniferous fossils and their bearing on the Viséan palaeogeography of Asia. Publ. Brit. Mus. (Nat. Hist.), 1-118, 17 pls.

(1955): A history of the classification of the phylum Brachiopoda. Ibid., 1-124.

Murata, Masafumi (1961): On the geological structure of the Akiyoshi plateau (in japanese with English abstract). Contr. Inst. Geol. Palaeont. Tohoku Univ., (53), 1-46.

Okimura, Yuji (1958): Biostratigraphical and palaeontological studies on the endothyroid foraminifera from the Atetsu limestone plateau, Okayama Prefecture, Japan. Jour. Sci. Hiroshima Univ., [c], 2, (3), 235-264, 5 pis.

(1963): Foraminiferal zones underlying the Profusulinella beppensis zone of the Akiyoshi limestone Group. Geol. Rep. Hiroshima Univ., (12), 305-318, 1 pl.

Onuki, Yoshio (1956): Geology of Iwate Prefecture; Geology of the Kitakami mountainland (in japanese). Publ. Iwate Prefecture. 1-189.

OzAKI, Kinemon (1939): On some Lower Carboniferous brachiopods from central Hunan, China. Jour. Sci. Inst. Shanghai, [2], 2, 225-282, 9 pls.

Ozawa, Yoshiaki (1925): Palaeontological and stratigraphical studies on the Permo. Carboniferous limestone of Nagato, Pt. 2, Palaeontology. Jour. Fac. Sci. Imp. Univ. Tokyo, 45, (6), 1-90, 14 pls.

Paeckelmann, W. (1931): Die Brachiopoden des deutschen Unterkarbons. 2 Teil, Die productinae und Productus-ähnlichen chonetinae. Abhandl, Preuss. Geol. Landes., N.F., 136, $1-352,41$ pls. 
Reed, F.R.C. (1925): Upper Carboniferous fossils from Chitral and the Pamirs. Palaeont. Indica, N.S., 6, (4), 1-134, 5 pls.

(1927): Palaeozoic and Mesozoic fossils from Yunnan. Ibid., N.S., 10, (1), 1-291, 20 pls.

СарычевА, Т.Г., СокольсКАЯ, А.Н., БЕзносовА, Г.А., и МАксимовА, С.В. (1963): Брахиоподы и палеогеография карбона кузнецкой котловины. ТРуды Палеонт. ИНСТ. АНСССР, 95, 1-406, 64 Табл.

Sato, Toshihiko (1956): On the Tateishi Formation and its Carboniferous coral fauna in the northeastern part of the Abukuma massif, Japan. Sci. Rep. Tokyo. Kyoiku Daigaku, [C], 4, (36), 235--261, 4 pls.

Сокольская А.Н. (1954): Строфомениды Руской Платформы. ТРуды Палеонт. ИНСТ. АНСССР, $51,1-191,18$ Табл.

Stuckenberg, A. (1905): Die Fauna der oberkarbonischen Suite des Wolgadurchbruches. Mem. Com. Geol., N.S., 23, 1-144, 13 pls.

Tachibana, Koichi (1956): New spiriferids from the Lowest Carboniferous of the Nagasaka district, Kitakami mountainland, northeast Japan. Sci. Rep. Fac. Art. Literat., Nagasaki Univ., (5), 11-16, 1 pls.

Ting, V.K. and Grabau, A.W. (1934): The Carboniferous of China and its bearing on the classification of the Mississippian and Pennsylvanian. Rep. 16 Intern. Geol. Congr., Washington, 1933, 1-17.

Tolmatchoff, I.P. (1926): Lower Carboniferous fauna, Kuznetsk coal field, Altai, Siberia. Amer. Jour, Sci., [5], 11, 411-422.

Toriyama, Ryuzo (1954 a): Geology of Akiyoshi. Part 1, Studies of the Akiyoshi limestone Group. Mem. Fac. Sci. Kyushu Univ., [D], 4, (1), 39-97.

- $(1954$ b) : Geology of Akiyoshi. Part 2, Stratigraphy of the non-calcareous groups developed around the Akiyoshi limestone Group. Ibid., [D], 5, (1), 1-46.

(1958): Geology of Akiyoshi. Part 3, Fusulinids of Akiyoshi. Ibid., [D], 7, 1-264, 48 pls.

Vaughan, A. (1905): The palaeontological sequence in the Carboniferous limestone of the Bristol area. Quart. Jour. Geol. Soc., 61, 181-308, 8 pls.

- (1908): On the faunal succession in the Carboniferous rocks at Loughshinny. Ibid.,

64, 436-474, 2 pls.

- (1915): The correlation of Dinantian and Avonian. Ibid., 71, (1), 1-52, 7 pls.

WAagen, W. (1883): Salt Range fossils, Palaeont. Indica, [13], Part 4, (2), 391-546, 20 pls.

Weller, S. (1914): The Mississippian brachiopods of the Mississippi valley basin. Illinois State Geol. Surv., Mon. 1, 1-508, 83 pls.

YAmagrwa, Nobuo and OTA, Masamichi (1962): Faunas and correlation of "Uzura" quarry, Akiyoshi, southwest Japan. Part 1, corals, Bull. Akiyoshi-Dai Sci. Mus., (2), 87-93, 2 pls.

YANAGIDA, Juichi (1962): Carboniferous brachiopods from Akiyoshi, southwest Japan. Part 1, Mem. Fac. Sci., Kyushu Univ., 12, (1), 87-127, 8 pls.

Yanishewsky, M. (1918): Materials for study of the Lower Carboniferous fauna of Ferghana. Mém. Com. Géol., N.S., 162, 1-145, 8 pls.

Yokoyama, Tsuruo (1957): Notes on some Carboniferous corals from Taishaku district, Hiroshima Prefecture, Japan. Jour, Sci. Hiroshima Univ., [C], 2, (1), 73-82, 3 pls. 
Juichi YANAGIDA

Carboniferous Brachiopods from Akiyoshi, Southwest Japan

Part II

Plates 25-28 
Plate 25 


\title{
Explanation of Plate 25
}

\author{
(all figures $\times 3$ )
}

Figs. 1-5. Rugicostella nystiana (DE KONINCK) ..................... page 114

1a-d. Respectively anterior, posterior, ventral, and lateral views of a pedicle valve, GK-D 30079.

2a-d. Respectively ventral, lateral, anterior, and posterior views of an incomplete pedicle valve, GK-D 30081.

3a-c. Respectively ventral, anterior, and lateral views of an incomplete pedicle valve, GK-D 30080.

4a-d. Respectively lateral, anterior, ventral, and posterior views of an incomplete pedicle valve, GK-D 30105.

5. Anterior part of an incomplete pedicle valve, GK-D 30082.

Photos by YANAGIDA with whitening. 


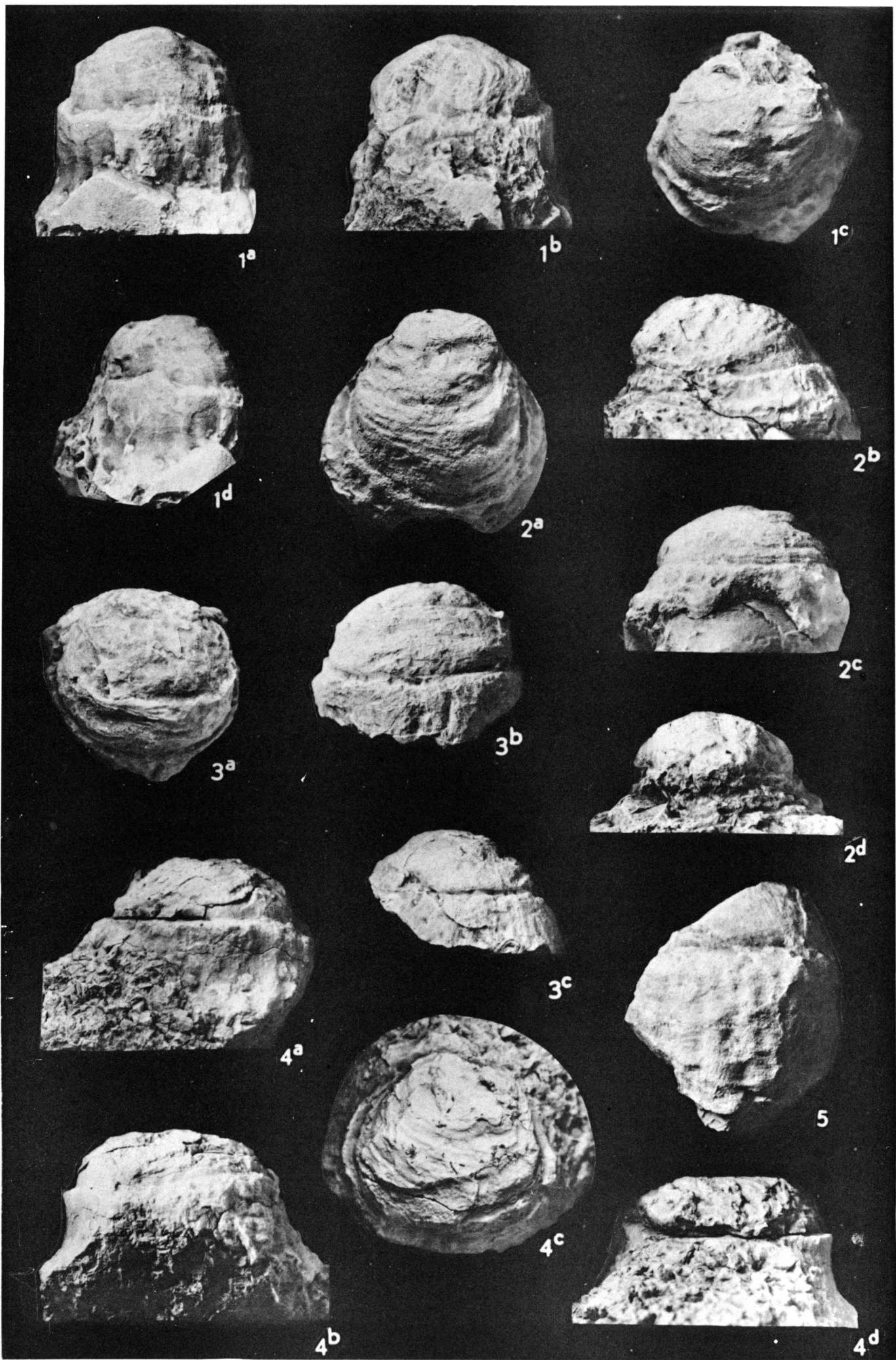

J. YANAGIDA : Carboniferous Brachiopods from Akiyoshi 
Plate 26 


\section{Explanation of Plate 26}

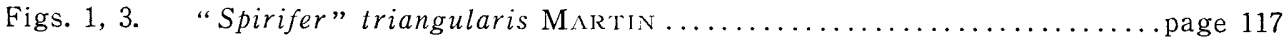

1a-d. Respectively dorsal, ventral, posterior, and lateral views of specimen GK-D 30109, x 3.5.

le. Enlarged view of a part of anterior region to show the ornament, ca. x 14 .

3a-c. Respectively posterior, ventral, and lateral views of a pedicle valve, GK-D $30090, \times 3.5$.

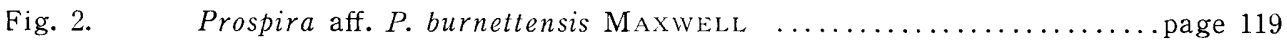

2a-c. Respectively ventral, lateral, and posterior views of a pedicle valve, GK-D 30091, x 4.

2d. Enlarged view of a part of anterior region to show the delicate ornament, ca. x 13.

Photos by YANAGIDA with whitening. 

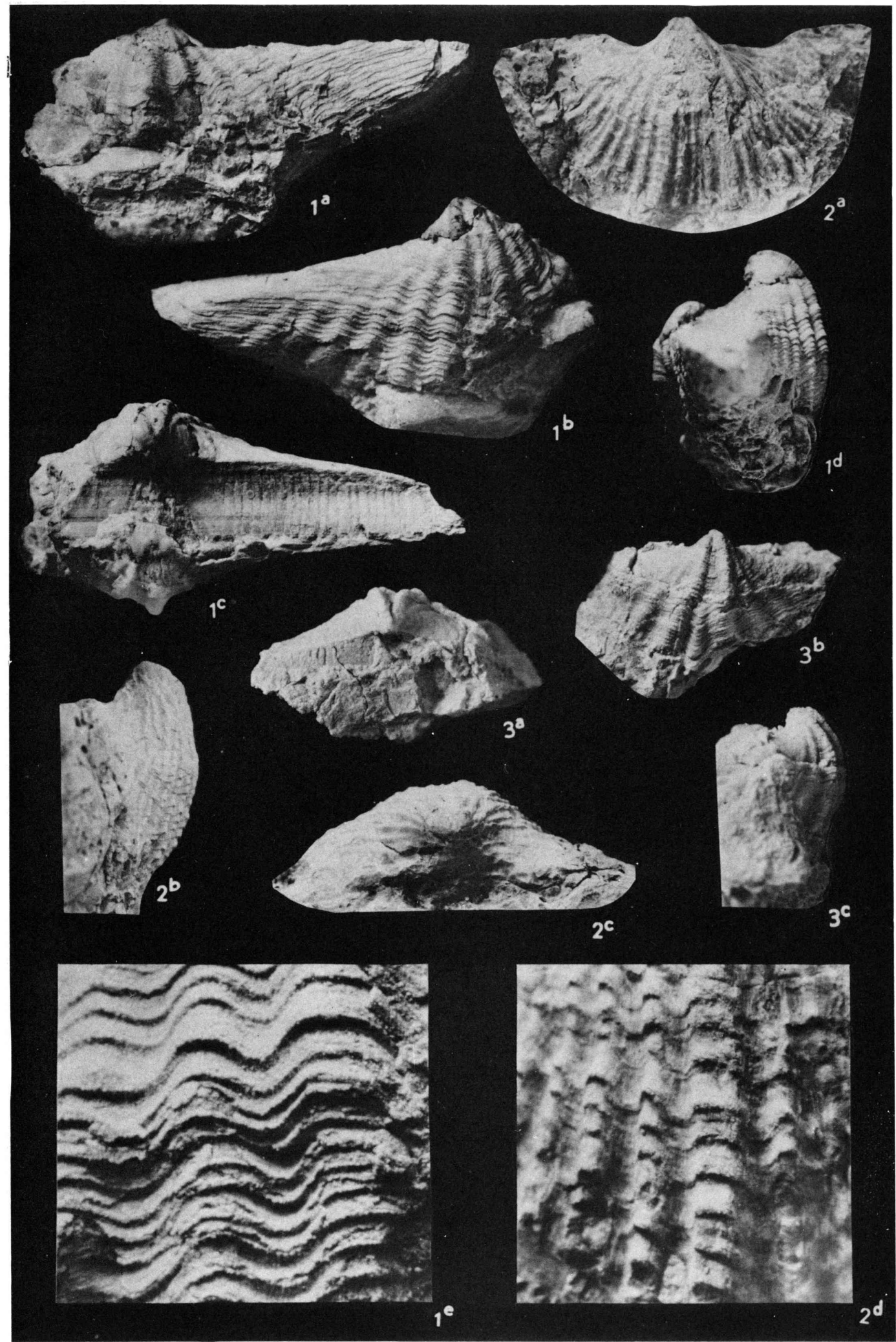

J. YANAGIDA: Carboniferous Brachiopods from Akiyoshi 
Plate 27 


\section{Explanation of Plate 27}

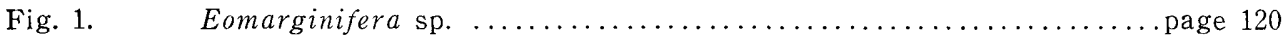

1a-c. Lateral, ventral, and posterior views of an internal mould of pedicle valve, GK-D 30099, x 2.5.

Figs. 2-8. Rugosochonetes aff. R. hardrensis (PHILliPs).............................. 115

2. Rubber replica of pedicle valve, GK-D 30087, x 3.5.

3, 6. Incomplete pedicle valves, GK-D 30086, and GK-D 30085, x 3.5.

$4,5,7,8$. Incomplete interiors of brachial valves, GK-D 30083, GK-D 30084, GK-D 30088, and GK-D 30089, x 3.5 .

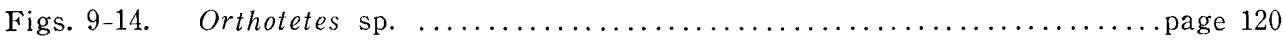

9. External mould of an incomplete pedicle valve, GK-D 30093, x 1.

10. Anterior part of an internal mould of brachial valve, GK-D 30110, x 1 .

11. Plaster cast of an incomplete brachial valve, GK-D 30107, x 1 .

12, Posterior part of an incomplete brachial valve, GK-D 30106, x 1 .

13. Incomplete brachial valve, GK-D 30094, x 1.

14. Internal cast of an incomplete brachial valve, GK-D 30108, x 1.

Photos by YANAGIDA with whitening. 

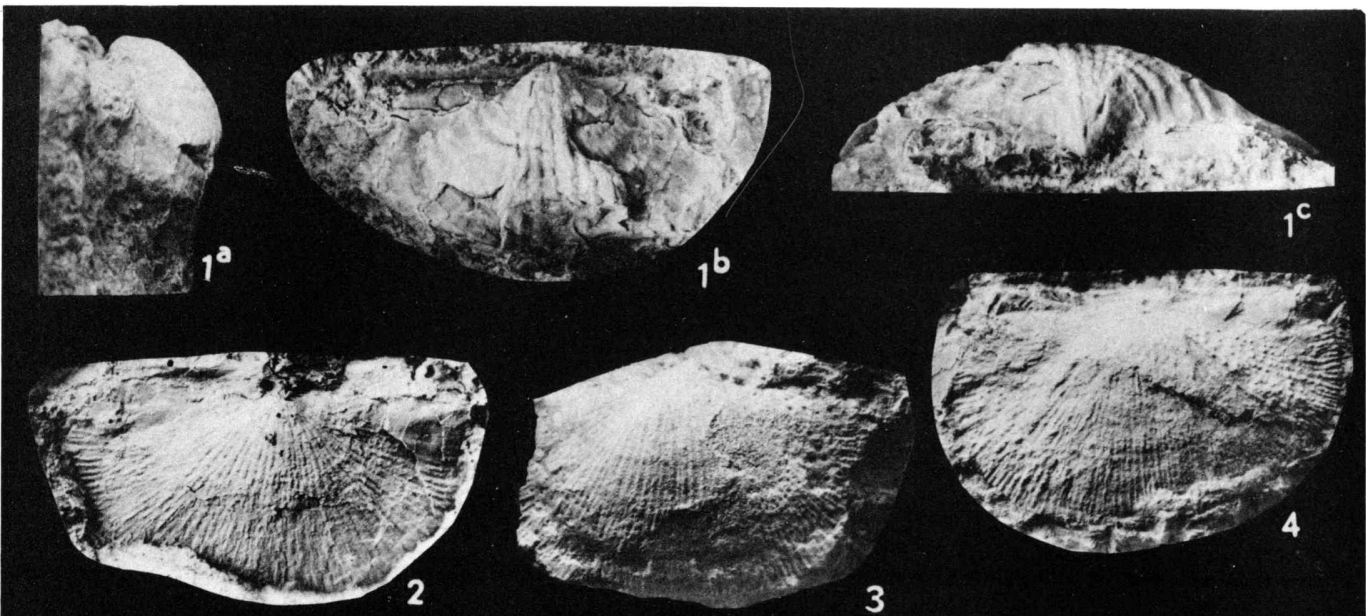

3

हैy

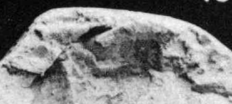


Plate 28 


\section{Explanation of Plate 28}

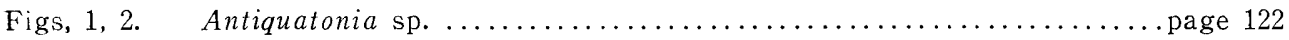

1a-d. Respectively ventral, lateral, posterior, and anterior views of a pedicle valve, GK-D 30104, ×2.

2a-d. Respectively lateral, ventral, posterior, and anterior views of a pedicle valve, GK-D 30103, ×2.

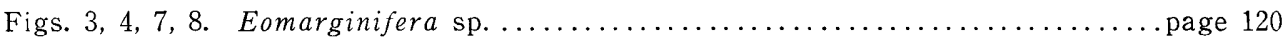

3a-c. Respectively posterior, ventral, and lateral views of a pedicle valve, GK-D $30096, \times 2.5$.

4. Incomplete pedicle valve, GK-D 30098, $\times 2.5$.

7. Incomplete pedicle valve, GK-D 30095, $\times 2.5$.

8. External mould of an incomplete brachial valve, GK-D $30097, \times 2.5$.

Figs. 5, 6. Dictyoclostus sp.................................... page 121

5a-c. Ventral, posterior, and lateral views of a pedicle valve, GK-D 30101, $\times 2$.

6a-c. Ventral, lateral, and anterior views of external mould of a brachial valve, GK-D 30102, ×2.5.

Photos by Yanagida with whitening. 


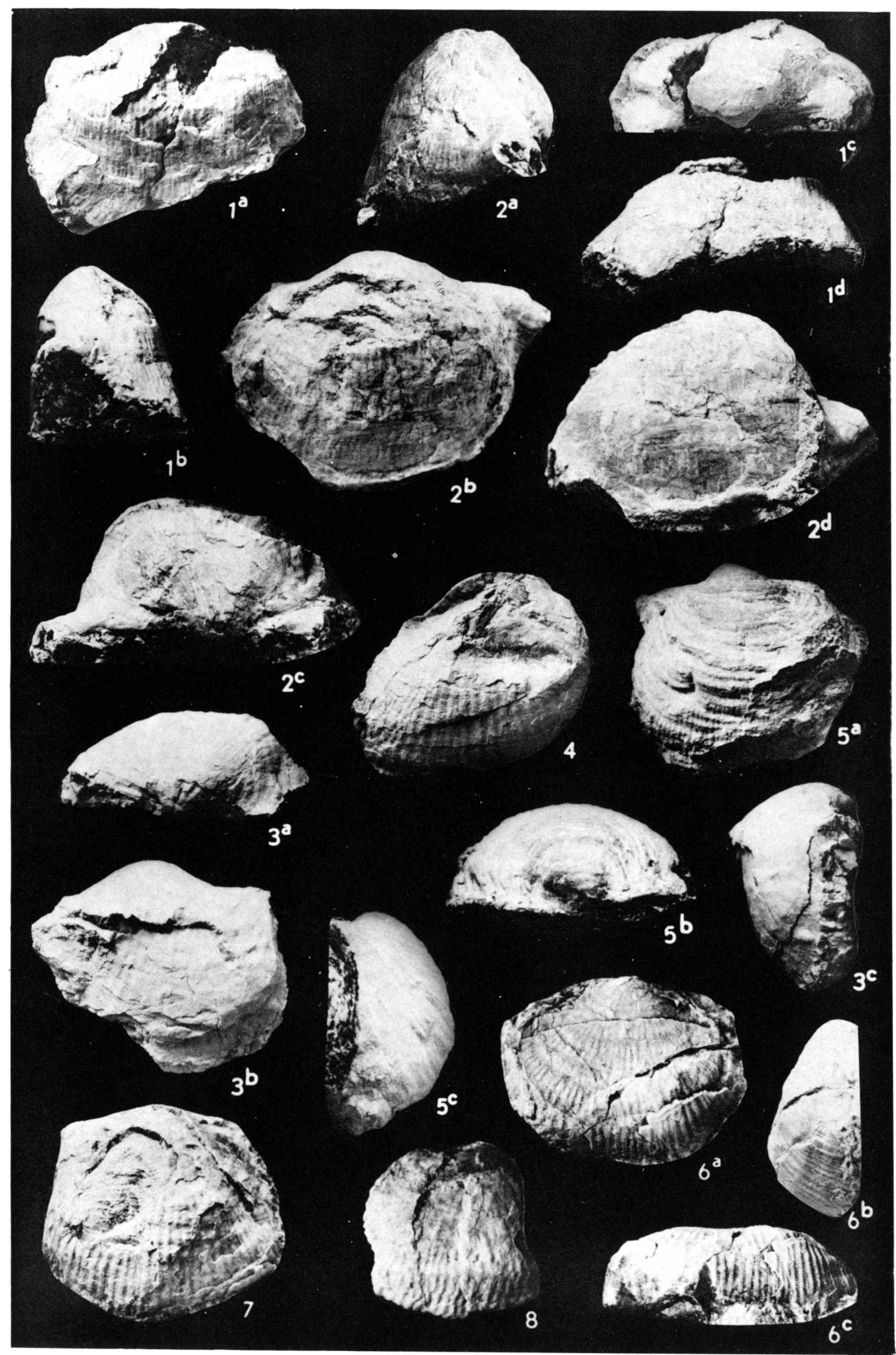

J. YANAGIDA: Carboniferous Brachiopods from Akiyoshi 